
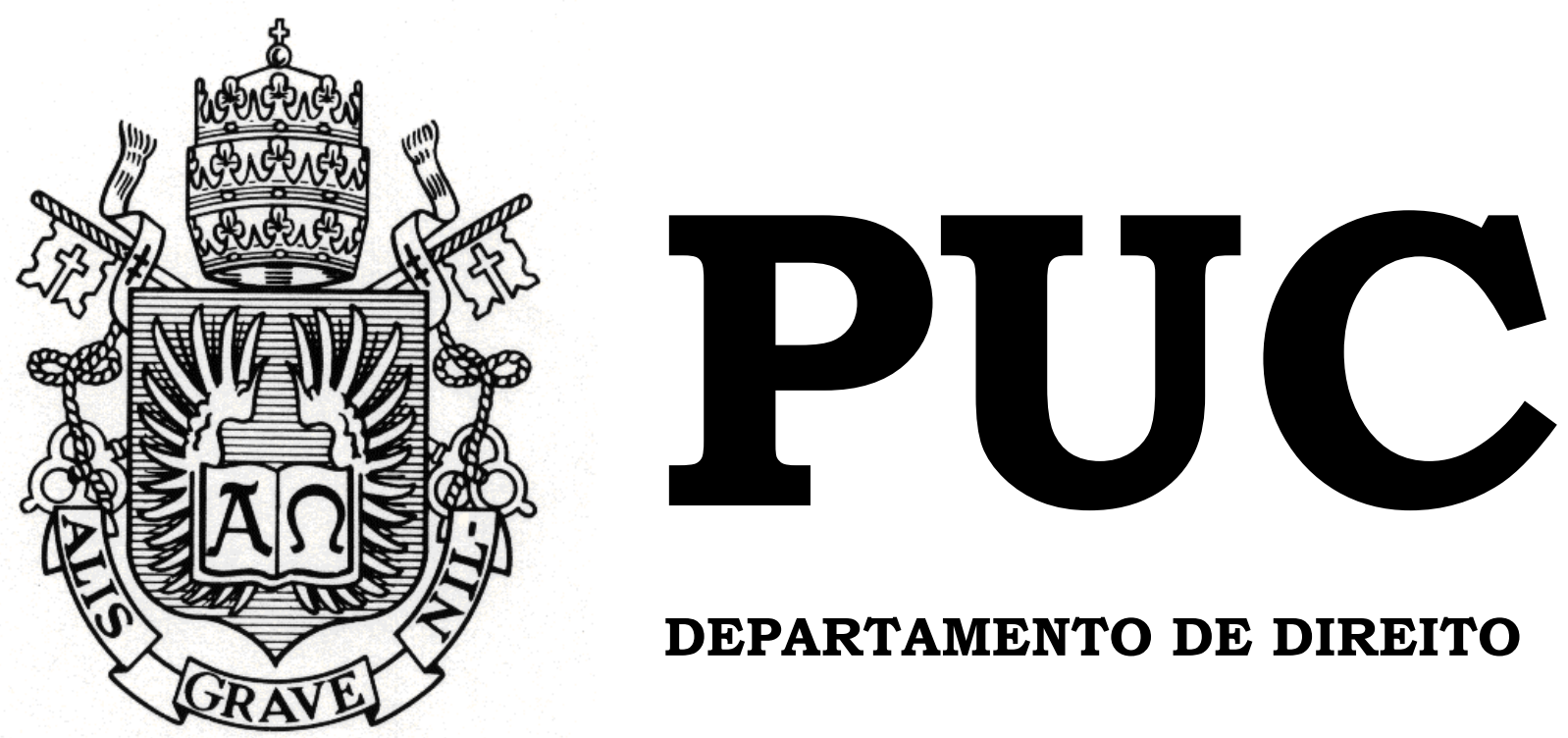

DEPARTAMENTO DE DIREITO

\title{
DIVÓRCIO COLABORATIVO: O MÉTODO CONSENSUAL, EXTRAJUDICIAL E MULTIDISCIPLINAR DE DISSOLUÇÃO DE VÍNCULOS CONJUGAIS
}

Por

VICTÓRIA DE SÁ PEREIRA MONJARDIM

ORIENTADOR: Bruno Vaz de Carvalho

2019.1

PONTIFÍCIA UNIVERSIDADE CATÓLICA DO RIO DE JANEIRO

RUA MARQUÊS DE SÃO VICENTE, 225 - CEP 22451-900

RIO DE JANEIRO - BRASIL 


\title{
DIVÓRCIO COLABORATIVO: O MÉTODO CONSENSUAL, EXTRAJUDICIAL E MULTIDISCIPLINAR DE DISSOLUÇÃO DE VÍNCULOS CONJUGAIS
}

\author{
por \\ VICTÓRIA DE SÁ PEREIRA MONJARDIM

\begin{abstract}
Monografia apresentada ao
Departamento de Direito da

Pontifícia Universidade Católica do

Rio de Janeiro (PUC-Rio) como requisito parcial para a obtenção do Titulo de Bacharel em Direito.
\end{abstract}

Orientador: Bruno Vaz de Carvalho 


\section{AGRADECIMENTOS}

À minha mãe, Ana Maria de Sá Pereira. Pela coragem inspiradora que me motiva a ser melhor em tudo que eu faço; pelo amor incondicional que me transmite segurança para perseguir os meus sonhos e pelo apoio do qual precisei pra chegar aqui e preciso para continuar evoluindo.

À minha avó, Flora Penna de Sá Pereira. Por me ensinar a ler e escrever, por me despertar o amor pela vida acadêmica e pela relação de carinho que transcende esta vida.

À minha psicanalista, Sandra Maria Martins Pereira. Por me ensinar a preencher algumas faltas, descobrir outras e aprender com as quais eu convivo.

À minha chefe Juliana Ituassú. Por me ensinar muito mais do que Direito das Famílias e pelas risadas que tornaram a dura reta final da graduação no período mais leve e divertido da minha vida.

Ao meu mentor, Bruno Vaz de Carvalho. Por me ajudar a descobrir minha vocação, pelo incentivo incrível e por ser um exemplo do que eu mais admiro em um advogado, a combinação entre ciência e arte.

À minha melhor amiga, Camila Zadra de Mattos. Por me ensinar o verdadeiro significado de amizade e cumplicidade; pelo amor, admiração e respeito recíprocos e incondicionais.

Ao meu namorado, Pedro Henrique Amorim Morales. Por ser um exemplo de dedicação e empenho; pela parceria e apoio que me proporcionaram segurança e acolhimento e, principalmente, pelo amor leve que transborda admiração. 


\section{RESUMO}

MONJARDIM, Victória de Sá Pereira. Divórcio colaborativo: o método consensual, extrajudicial e multidisciplinar de dissolução de vínculos conjugais. Rio de Janeiro, 2019. 69 p. Monografia de final de curso. Departamento de Direito da Pontifícia Universidade Católica do Rio de Janeiro - PUC-Rio.

O presente trabalho tem como objetivo apresentar o método americano de dissolver vínculos conjugais de forma extrajudicial, consensual e multidisciplinar aplicado ao direito brasileiro. Será feito, de início, paronâma histórico do divórcio no ordenamento jurídico brasileiro. Em seguida será descrito como nasceram as Práticas Colaborativas no contexto americano, como se deu sua entrada no Brasil e como elas se refletem muito coerentes com a atual filosofia jurídica nacional. Por fim, será demonstrado o ponto de congruência entre o método e o Direito das Famílias, por meio de sua aplicação ao instituto do divórcio, que envolve também a transformação da postura do advogado.

Palavras-Chave: Direito das Famílias; Divórcio; Panorama Histórico; Modelo Tradicional; Práticas Colaborativas; Diálogo; Multidisciplinariedade; Divórcio Colaborativo; Protagonismo; Advogado Colaborativo. 


\section{SUMÁRIO}

TÍTULO I - HISTÓRICO LEGAL DO CASAMENTO NO BRASIL E SURGIMENTO DO DIVÓRCIO ........................................................5

Capítulo $1^{\circ}$ - Contexto Anterior à 1977 - Primeiras Demandas Divorcistas 5

Capítulo $2^{\circ}$ - A Emenda 9/77 - O Advento da Lei do Divórcio 9

Capítulo $3^{\circ}$ - Constituição de 1988 e Emenda 66/2010 - Família como Espaço de Realização Pessoal e o Divórcio Sem Culpa ............................. 12 TÍTULO II - AS PRÁTICAS COLABORATIVAS ...................................17

Capítulo $1^{\circ}$ - Surgimento das Práticas Colaborativas .................................17

Capítulo $2^{\circ}$ - Práticas Colaborativas No Brasil .........................................23

Capítulo $3^{\circ}$ - Dispositivos do Ordenamento Jurídico Brasileiro................24

TÍTULO III - DIVÓRCIO COLABORATIVO ...........................................32

Capítulo $1^{\circ}$ - Aplicação das Práticas Colaborativas ao Divórcio................32

Capítulo $2^{\circ}$ - O Resgate do Paradigma do Advogado das Famílias .........51

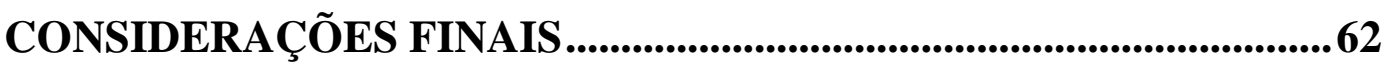

REFERÊNCIAS BIBLIOGRÁFICAS .................................................65 


\section{TíTULO I - HISTÓRICO LEGAL DO CASAMENTO NO BRASIL E SURGIMENTO DO DIVÓRCIO}

\section{Capítulo 1ํ - Contexto Anterior à 1977 - Primeiras Demandas Divorcistas}

Em função da nossa história colonizatória marcada por costumes portugueses, é notória a tradição religiosa no Brasil. Isso influenciou diretamente o desenvolvimento do divórcio no país, que aconteceu de forma extremamente lenta, tranformando sua institucionalização, o que hoje enxergamos como direito, numa verdadeira luta.

Com a proclamação da independência e a consequente instauração da monarquia, que veio a durar até 1899, a influência direta da Igreja em matéria de casamento ficou marcada pela edição do Decreto de 3 de novembro $^{1}$ de 1827, que formalizou a jurisdição eclesiástica nas questões matrimoniais. Isto, porque o referido diploma legal afirmou expressamente a obrigatoriedade das disposições do Concílio de Trento e da Constituição do Arcebispo da Bahia.

Em 1861, a norma de maior representatividade na matéria foi o Decreto $\mathrm{n}^{\circ} 1.144^{2}$, de 11 de setembro deste ano. Tal decreto representou um avanço significativo para os parâmetros da época, tendo em vista que não só aceitava, mas também regulava o casamento entre pessoas de seitas diferentes nos termos do que preceituavam suas próprias religiões. É o que se verifica no artigo transcrito a seguir:

Art. $1^{\circ}$ Os effeitos civis dos casamentos celebrados na fórma das Leis do Imperio serão extensivos:

\footnotetext{
${ }^{1}$ BRASIL. Decreto de 3/11/1827. Disponível em: <http://www.planalto.gov.br/ccivil_03/leis/lim/LIM-3-11-1827.htm>. Acesso em: 20 mai. 2019.

${ }^{2}$ BRASIL. Decreto $n^{\circ} 1.144$ de 1861. Disponível em:

<https://www2.camara.leg.br/legin/fed/decret/1824-1899/decreto-1144-11-setembro-1861-

555517-publicacaooriginal-74767-pl.html>. Acesso em: 20 mai. 2019.
} 
$1^{\mathrm{o}}$ Aos casamentos de pessoas que professarem Religião differente da do Estado celebrados fóra do Imperio segundo os ritos ou as Leis a que os contrahentes estejão sujeitos.

Além disso, nos termos do artigo $2^{\circ}$, a autoridade civil passou a ser a competente tanto para dispensar os impedimentos existentes, quanto para julgar a nulidade do casamento:

Art. $2^{\circ} \mathrm{O}$ Governo regulará o registro e provas destes casamentos, e bem assim o registro dos nascimentos e obitos das pessoas que não professarem a Religião Catholica, e as condições necessarias para que os Pastores de Religiões toleradas possão praticar actos que produzão effeitos civis.

Com a delegação desta atribuição, retirando a prerrogativa exclusiva da Igreja para uma entidade civil, foi possível que esse julgamento passasse a ser feito de forma minimamente imparcial.

No que tange as aspirações divorcistas, foi no ano de 1890 a primeira menção ao termo divórcio no ordenamento jurídico pátrio. O Decreto $\mathrm{n}^{\mathrm{o}} 181^{3}$ de 24 de Janeiro dedicou um capítulo inteiro ao tema. Isso não significa, entretanto, que já era atribuído o mesmo significado que entendemos como correto atualmente, já que seu artigo 88 dispunha:

Art. 88. $\mathrm{O}$ divorcio não dissolve o vinculo conjugal, mas autoriza a separação indefinida dos corpos e faz cassar o regimen dos bens, como si o casamento fosse dissolvido.

Uma análise sistemática do Decreto permite afirmar que, na verdade, ele estabelece a morte de um dos cônjuges como único meio de pôr fím ao casamento válido (art. $93^{4}$ ). Nos termos do artigo $82^{5}$, era taxativo o rol de possíveis motivos do pedido do divórcio, quais fossem: adultério, injuría

\footnotetext{
${ }^{3}$ BRASIL. Decreto $n^{o} 181$ de 1890. Disponível em: <http://www.planalto.gov.br/ccivil_03/decreto/1851-1899/D181.htm>. Acesso em: 20 mai. 2019.

${ }^{4}$ Art. 93. O casamento válido só se dissolve pela morte de um dos conjuges, e neste caso procederse-ha a respeito dos filhos e dos bens do casal na conformidade do direito civil."

${ }^{5}$ Art. 82. O pedido de divorcio só póde fundar-se em algum dos seguintes motivos:

$\S 1^{\circ}$ Adulterio.

$\S 2^{\circ}$ Sevicia, ou injuria grave.

$\S 3^{\circ}$ Abandono voluntario do domicilio conjugal e prolongado por dous annos continuos.

$\S 4^{\circ}$ Mutuo consentimento dos conjuges, si forem casados ha mais de dous annos.
} 
grave, abandono voluntário de domicílio conjugal por dois anos contínuos e mútuo consentimento dos cônjuges, se casados há mais de 2 anos.

Mesmo que qualquer um desses motivos fosse alegado e devidamente comprovado, o divórcio da época não permitia, como hoje, o novo casamento. Em outras palavras, o convívio conjugal poderia ser extinto, mas o vínculo matrimonial permanecia. Nesse sentido, o conceito de divócio à época pode ser comparado com o instituto da separação que temos atualmente.

É facilmente perceptível a intenção moralista por trás de todas as opções. Além de implicar enorme intromissão estatal na vida privada das pessoas, todas as alternativas eram marcadas por um gritante caráter de gênero, recriminando a mulher.

Somente por meio da constituição de $1891^{6}$, foi possível a separação ao menos formal - entre Igreja e Estado. O ano de 1893 foi importantíssimo para o movimento divorcista, já que foi quando o Deputado Érico Marinho apresentou ao parlamento a primeira proposição nesse sentido, seguido pelo também Deputado Martinho Garcez que se esforçou para implacar o projeto "divórcio vincular" . Ambas as tentativas foram frustradas.

A partir de codificação do Direito Civil Brasileiro ${ }^{8}$, o que antes era chamado de divórcio pelo Decreto 181/1890, passou a adotar a nomenclatura de desquite. A lei previa as seguintes hipóteses de dissolução da sociedade conjugal:

"Art. 315. A sociedade conjugal termina:

I. Pela morte de um dos cônjuges.

II. Pela nulidade ou anulação do casamento.

III. Pelo desquite, amigável ou judicial."

\footnotetext{
${ }^{6}$ BRASIL. Constituição Brasileira de 1891. Disponível em:

<http://www.planalto.gov.br/ccivil_03/constituicao/constituicao91.htm>. Acesso em: 20 mai. 2019.

${ }^{7}$ PEREIRA, Rodrigo da Cunha. Divórcio Teoria e Prática. $2^{\mathrm{a}}$ ed. Rio de Janeiro: G Z Editora, 2010. p. 9.

${ }^{8}$ BRASIL. Código Civil de 1916. Disponível em:

<http://www.planalto.gov.br/ccivil_03/leis/13071.htm>. Acesso em: 20 mai. 2019.
} 
As causas taxativas que poderiam acarretar desquite foram repetidas do Decreto 181/1890, quais eram, adultério, injúria grave, abandono voluntário de domicílio conjugal por dois anos contínuos e mútuo consentimento dos cônjuges, desde que casados ha pelo menos 2 anos. A novidade trazida pela lei, portanto, foi a introdução deste novo termo, o desquite.

O desquite, amigável ou litigioso, punha fim ao regime de bens, mas não autorizava o fim do vínculo conjugal e, portanto, impedia novas núpicas. Percebe-se, então, a resistência quanto à dissolubilidade do casamento, o que está novamente relacionado à cultura religiosa mencionada anteriormente.

Fundamental aqui ressaltar o peso semântico deste termo à época. A etimologia da palavra desquite nos leva a inferir que trata-se de termo utilizado para descrever aquele que não estava quite com a sociedade, ou seja, que havia pendência para com a comunidade. Tornou-se rapidamente termo pejorativo ${ }^{9}$ e transformou-se em verdadeiro estigma, principalmente para as desquitadas.

O direito brasileiro foi, de modo geral, marcado por Constituições que ora não tratavam do tema, como é o caso das Cartas de $1824^{10}$ e $1891^{11}$, ora colocavam o casamento como indissolúvel, como aconteceu nos documentos seguintes, conforme se verifica pelos seguintes dispostivos as Cartas de $1934^{12}, 1937^{13}, 1946^{14}$ e $1967^{15}$, respectivamente:

\footnotetext{
${ }^{9}$ FIORI, Vera. Divórcio à brasileira. Disponível em: <https://emais.estadao.com.br/noticias/geral,divorcio-a-brasileira,22666>. Acesso em: 11 jun. 2019.

${ }^{10}$ BRASIL. Constituição de 1824. Disponível em:

<http://www.planalto.gov.br/ccivil_03/Constituicao/Constituicao24.htm>. Acesso em: 20 mai. 2019.

${ }^{11}$ BRASIL. Constituição Brasileira de 1891. Acesso em: 20 mai. 2019.

12 BRASIL. Constituição de 1934. Disponível em:

<http://www.planalto.gov.br/ccivil_03/constituicao/constituicao34.htm>. Acesso em: 20 mai. 2019.

${ }^{13}$ BRASIL. Constituição de 1937. Disponível em:

<http://www.planalto.gov.br/ccivil_03/constituicao/constituicao37.htm>. Acesso em: 20 mai. 2019.

14 BRASIL. Constituição de 1947. Disponível em:

<http://www.planalto.gov.br/ccivil_03/constituicao/constituicao46.htm>. Acesso em: 20 mai. 2019.

${ }^{15}$ BRASIL. Constituição de 1967. Disponível em:

<http://www.planalto.gov.br/ccivil_03/constituicao/constituicao67emc69.htm>. Acesso em:

20 mai. 2019.
} 
Art 144 - A família, constituída pelo casamento indissolúvel, está sob a proteção especial do Estado.

Parágrafo único - A lei civil determinará os casos de desquite e de anulação de casamento, havendo sempre recurso ex officio, com efeito suspensivo.

Art 124 - A família, constituída pelo casamento indissolúvel, está sob a proteção especial do Estado. Às famílias numerosas serão atribuídas compensações na proporção dos seus encargos.

Art 163 - A família é constituída pelo casamento de vínculo indissolúvel e terá direito à proteção especial do Estado.

Art. 175. A família é constituída pelo casamento e terá direito à proteção dos Podêres Públicos.

$\S 1^{\circ} \mathrm{O}$ casamento é indissolúvel.

A noção de casamento indissolúvel, até então tão enrraizada no nosso ordenamento jurídico, veio finalmente a ser alterada no ano de 1977.

\section{Capítulo 2º - A Emenda 9/77 - O Advento da Lei do Divórcio}

Conforme amplamente discutido anteriormente, o divórcio sempre foi um tema controverso. Prova disso é que a Emenda Constitucional 9/77 ${ }^{16}$, que introduziria o divórcio definitivamente no ordenamento jurídico brasileiro, proposta pelo Presidente da República Ernesto Geisel com base na Emenda Constitucional $8 / 77^{17}$ e no Ato Institucional $5 / 68^{18}$, precisou ter seu quórum de aprovação diminuído.

Esclarecendo, o que ocorria era que, por conta da Emenda Constitucional 1 de $1969^{19}$, os chefes militares que compunham o governo da época estabeleceram que as Emendas Constitucionais só seriam aprovadas se houvesse anuência de dois terços das duas casas do Congresso Nacional, Câmara dos Deputados e Senado Federal. É o que traduz o seu artigo 48:

\footnotetext{
${ }^{16}$ BRASIL. Emenda Constitucional 9/77. Disponível em: <https://presrepublica.jusbrasil.com.br/legislacao/103919/emenda-constitucional-9-77>. Acesso em: 20 mai. 2019.

${ }^{17}$ BRASIL. Emenda Constitucional 8/77. Disponível em: <http://www.planalto.gov.br/ccivil_03/Constituicao/Emendas/Emc_anterior1988/emc08-77.htm>. Acesso em: 20 mai. 2019.

18 BRASIL. Ato Institucional 5/68. Disponível em: <http://www.planalto.gov.br/ccivil_03/AIT/ait05-68.htm>. Acesso em: 20 mai. 2019.

${ }^{19}$ BRASIL. Emenda Constitucional 1 de 1969. Disponível em: <http://www.planalto.gov.br/ccivil_03/constituicao/emendas/emc_anterior1988/emc01-69.htm>. Acesso em: 20 mai. 2019.
} 
Art. 48. Em qualquer dos casos do artigo anterior, itens I e II, a proposta será discutida e votada em reunião do Congresso Nacional, em duas sessões, dentro de sessenta dias, a contar da sua apresentação ou recebimento, e havida por aprovada quando obtiver, em ambas as votações, dois terços dos votos dos membros de suas Casas.

Considerando que propostas divorcistas anteriores ${ }^{20}$ não conseguiram alcançar esse quórum, tendo em vista a enorme divergência quanto ao tema, foi necessária a edição da Emenda Constitucional 8/77, por meio da qual o citado artigo 48 passaria a ter a seguinte redação:

Art, 48 Em qualquer dos casos do artigo anterior, a proposta será discutida e votada em reunião do Congresso Nacional, em duas sessões, dentro de noventa dias a contar de seu recebimento, e havida por aprovada quanto obtiver, em ambas as sessões, maioria absoluta dos votos do total de membros do Congresso Nacional.

A diminuição significativa do número de congressistas necessários para aprovação de EC fez com que, finalmente, a EC 9/77 fosse aprovada. Isso representou uma alteração importantíssima no artigo 175 da Constituição Federal vigente na época. Antes, o referido artigo estava disposto da seguinte maneira:

Art. 175. A família é constituída pelo casamento e terá direito à proteção dos Podêres Públicos.

$\S 1^{\circ} \mathrm{O}$ casamento é indissolúvel.

Depois da diminuição do quórum, o objeto da consequente EC 9/77 foi justamente dar nova redação ao artigo 175 da Constituição estabelecendo que:

Art. $1^{\circ} \mathrm{O} \S 1^{\circ}$ do artigo 175 da Constituição Federal passa a vigorar com a seguinte redação:

Art. 175 -

$\S 1^{o}$ - O casamento somente poderá ser dissolvido, nos casos expressos em lei, desde que haja prévia separação judicial por mais de três anos.

\footnotetext{
${ }^{20}$ BRASIL. Ato Institucional 5/75. Disponível em: 〈https://presrepublica.jusbrasil.com.br/legislacao/103910/emenda-constitucional-5-75〉. Acesso em: 16 jun. 2019.
} 
Art. $2^{\circ}$ A separação, de que trata o $\$ 1^{\circ}$ do artigo 175 da Constituição, poderá ser de fato, devidamente comprovada em Juízo, e pelo prazo de cinco anos, se for anterior à data desta emenda.

Percebe-se, portanto, que além da demanda divorcista ter sido enfim atendida, que a palavra desquite foi abandonada pela legislação. A partir daí, passamos a adotar a nomenclatura "seperação judicial". Em que pese substituição necessária e adequada, o termo desquite seguiu sendo utilizado popularmente, revelando o estigma, ainda que retrógrado.

Ademais, percebe-se que, mesmo com o maior dos avanços divorcistas consubstanciado na Emenda Constitucional 9/77, ainda seguimos submetidos a requisitos temporais - e de outras naturezas ${ }^{21}$ - para que o divórcio ocorresse, requisitos estes que se revelam arbitrários e crueis, considerando que a convivência pode se tornar insuportável para ambas as partes no final de um relacionamento.

Aprovada a EC 9/77, ultrapassada a barreira formal anteriormente imposta pela constituição rapidamente foi editada lei ordinária para regulamentar a nova redação dada ao artigo 175 da Constituição. Esta lei foi batizada com o número $6.515 / 77^{22}$, cujo projeto final foi idealizado por representantes do Rio de Janeiro (Senador Nelson Carneiro) e Paraná (Senador Pedro Accioly Filho) ${ }^{23}$.

Além de tratar da separação judicial e divórcio, o referido diploma legal apresentou progresso em outras áreas do direito das famílias. A lei alterou, por exemplo, o artigo $240^{24}$ do Código Civil de 1916, tornando facultativa a adoção do nome do marido pela esposa no momento do matrimônio. Essa alteração foi feita por meio do artigo $50^{25}$ da Lei do Divórcio.

\footnotetext{
${ }^{21}$ BRASIL. Lei $n^{o} 6.515 / 77$. Artigo $4^{\circ}$ e $5^{\circ} \S 1^{\circ}$. Disponível em: <http://www.planalto.gov.br/ccivil_03/leis/16515.htm>. Acesso em: 20 mai. 2019.

22 BRASIL. Lei $n^{\circ}$ 6.515/77. Acesso em: 20 mai. 2019.

${ }^{23}$ CARVALHO NETO, Inacio de. Separação e Divórico Teoria e Prática. 2007. p. 94.

24 Art. 240. A mulher assume, pelo casamento, com os apelidos do marido, a condição de sua companheira, consorte e auxiliar nos encargos da família.

${ }^{25}$ Art 50 - São introduzidas no Código Civil as alterações seguintes:
} 
A diferença traçada por meio da Lei 6.151/77, portanto, entre a agora chamada separação judicial e o divórcio em si, é principalmente relativa a possibilidade ou não de contrair novas núpcias. Enquanto pessoas judicialmentes separadas passam a não mais ter o dever de coabitação e têm seu regime de bens interrompido, elas não poderão se casar novamente. Essa última hipótese só é contemplada em casos de divórcio propriamente dito. A separação judicial, portanto, representa uma etapa anterior ao divórcio.

Apesar de muito ter representado esta lei no caminho rumo à liberdade das pessoas por permitir, finalmente, que fosse possível se casar novamente depois do divórcio, é importante deixar claro que essa possibilidade se restringia a um único casamento depois do divórcio (art.38) ${ }^{26}$. Além disso, ainda se fazia necessária a indicação de culpa para justificar o divórcio (art. $40)^{27}$, permitindo, inclusive, invasão da esfera privada para que essa prova fosse produzida

Por isso, trata-se ainda de um reflexo da resistência anti divorcio muito presente na sociedade amparada também por influências religiosas que ainda pairavam sobre o Direito por conta daqueles que entendiam que o divórcio iria acabar com a instituição familiar.

\section{Capítulo $3^{\circ}$ - Constituição de 1988 e Emenda 66/2010 - Família como Espaço de Realização Pessoal e o Divórcio Sem Culpa}

A Constituição da República Federativa do Brasil de $1988^{28}$ é um dos textos constitucionais mais vanguardistas do mundo. Seguindo o panorâma histórico feito aqui, essa carta representou evolução principalmente por

\footnotetext{
Parágrafo único - A mulher poderá acrescer ao seus os apelidos do marido.

${ }^{26}$ Art 38 - O pedido de divórcio, em qualquer dos seus casos, somente poderá ser formulado uma vez.

${ }^{27}$ Art 40 - No caso de separação de fato, com início anterior a 28 de junho de 1977, e desde que completados 5 (cinco) anos, poderá ser promovida ação de divórcio, na qual se deverão provar o decurso do tempo da separação e a sua causa.

${ }^{28}$ BRASIL. Constituição de 1988. Disponível em:

<http://www.planalto.gov.br/ccivil_03/constituicao/constituicaocompilado.htm>. Acesso em: 20 mai. 2019.
} 
aceitar vários outros tipos de família, que não somente a relativa ao vínculo matrimonial. Assim como o arranjo familiar decorrente do casamento entre duas pessoas, a família monoparental, a união estável e a família substituta fazem parte do rol de modelos de família abarcados pelo texto constitucional.

É por isso que, como diz Jones Figueirêdo Alves citado por Maria Berenice Dias, hoje falamos em Direito das Famílias e não mais em Direito de Família. Segundo ela ${ }^{29}$, "a adição de uma simples consoante é capaz de sinteticamente dimensionar as várias possibilidades de arranjos familiares".

Além de expressamente alargar o escopo dos modelos familiares, a Carta estabelece que o afeto é tido como elemento estruturante da composição familiar. Este, sem dúvida, é o marco fundamental de uma nova interpretação do casamento que se distancia muito do único, autoritário e indissolúvel modelo matrimonial ao qual fomos submetidos no século passado.

Os conceitos de família e divórcio são hoje compreendidos pela ótica de autonomia privada. Isto significa que se trata de um espaço de realização pessoal ${ }^{30}$, que deve ser moldado de acordo com o subjetivismo de cada um para alcançar o que individualmente se entende por perpetuação de suas escolhas existenciais.

Tendo em vista a mudança de interpretação no que tange a finalidade da Família, ou como nos referimos hoje, das Famílias, a lógica autonomia privada afasta o pressuposto de procriação que outrora limitou o instituto e aproxima o Direito Brasileiro do que apresenta a realidade plural da nossa sociedade.

\footnotetext{
${ }^{29}$ DIAS, Maria Berenice. Manual de Direito das Famílias. $7^{\mathrm{a}}$ ed. São Paulo: Ed. Revista dos Tribunais, 2010. p. 28.

${ }^{30}$ Artigo 1.513 do Código Civil de 2002: "É defeso a qualquer pessoa, de direito público ou privado, interferir na comunhão de vida instituída pela família.
} 
No contexto pós constituição de 1988, a Emenda Constitucional $66 / 10^{31}$ foi possivelmente o passo mais importante dado pelo Direito das Famílias no caminho rumo à liberdade e ao afeto. Sem dúvida, é também um marco legal de suma importância para o tema do presente trabalho. A partir dela, o artigo $266^{32}$ da própria Constituição foi alterado em seu $\S 6^{\circ}$.

Até então, seu redação determinava que o casamento civil poderia ser “dissolvido pelo divórcio, após prévia separação judicial por mais de um ano nos casos expressos em lei, ou comprovada a separação de fato por mais de dois anos". Depois de 2010, o mesmo parágrafo passou a determinar, pura e simplesmente, que "o casamento civil pode ser dissolvido pelo divórcio" 33 . A partir daí, independentemente de prazo ou imputação de culpa, é permitida a dissolução do vínculo matrimonial.

Trata-se, portanto, simplesmente de ato de vontade das partes que, por qualquer que seja o motivo, não queiram manter o vínculo matrimonial. Foi uma verdadeira revolução no que tange o instituto do divórcio, tendo em vista que passou a ser totalmente desconsiderado pelo direito, aspectos morais, religiosos ou sociais pelos quais o casal eventualmente tenha encontrado diferenças irreconciliáveis. Nesse sentido, o Estado passou a respeitar as particularidades da vida privada e se abster de um juízo de valor no que tange um aspecto tão subjetivo das relações humanas.

Felizmente, a Lei 7.841/89 veio para finalmente revogar parte do artigo 40 da Lei 6.515/77 retirando a necessidade de imputação de culpa ${ }^{34} \mathrm{e}$ retirando o caráter transitório do divórcio direto. Isso significa não só respeito

\footnotetext{
${ }^{31}$ BRASIL. Emenda Constitucional 66/10. Disponível em: <http://www.planalto.gov.br/ccivil_03/constituicao/emendas/emc/emc66.htm>. Acesso em: 20 mai. 2019.

32 Texto Constitucional antes da Emenda 66/10: Art. 226. A família, base da sociedade, tem especial proteção do Estado. (...)§ $6^{\circ} \mathrm{O}$ casamento civil pode ser dissolvido pelo divórcio, após prévia separação judicial por mais de um ano nos casos expressos em lei, ou comprovada separação de fato por mais de dois anos.

33 Texto Constitucional depois da Emenda 66/10: Art. 226. A família, base da sociedade, tem especial proteção do Estado (...) $\S 6^{\circ} \mathrm{O}$ casamento civil pode ser dissolvido pelo divórcio.

${ }^{34} \mathrm{O}$ artigo 40 passa a ter a seguinte redação: Art. 40. No caso de separação de fato, e desde que completados 2 (dois) anos consecutivos, poderá ser promovida ação de divórcio, na qual deverá ser comprovado decurso do tempo da separação.
} 
ao Princípio da Intimidade e Privacidade ${ }^{35}$, como retira o peso de imputar culpa no final da relação que, por si só, já representava suficiente desgaste emocional.

Desde então, muito se discute que lugar passou a ocupar o instituto da separação judicial em nosso sistema, tendo em vista o advento da Emenda Constitucional 66 e as alterações na Lei do Divórcio referidas acima. Nas palavras de Maria Berenice Dias ${ }^{36}$ :

No momento em que se tornou possível a obtenção do divórcio mediante a mera comprovação da ruptura da vida em comum por dois anos consecutivos, institucionalizou-se o divórcio direto. Deixou de ser modalidade temporária de dissolução da sociedade conjugal tornando despicienda a dupla via procedimental. Superado o obstáculo que condicionava a concessão do divórcio a um termo inicial em data determinada, consolidou-se o divórcio como instituto autônomo, afastando a necessidade de prévia separação judicial como condição para ser deferido somente por meio do procedimento de conversão.

Também encontramos doutrina argumentando que o instituto subsiste $^{37}$, porque os artigos que tratam do assunto não foram expressamente revogados e, a depender do casal, pode ser benéfico dispor de um lapso temporal sem que o vínculo conjugal se desfaça, para que seja possível analisar se as partes de fato desejam o divórcio. Nesse sentido, também coloca Maria Berenice Dias que:

A única "vantagem" que se visualiza é, a possibilidade de se reverter a separação. No caso de os separados se reconciliarem podem, a todo tempo, restabelecer a sociedade conjugal "por ato regular do juiz" (art. 1.577 do CC). Já os divorciados que se arrependerem precisam casar novamente. Ou seja, a separação, ao contrário do divórcio, dispõe do que se poderia chamar de "cláusula de arrependimento". Esse único benefício se mostra deveras insignificante, até porque raros são os pedidos de reversão da separação de que se tem notícia. Há a necessidade de

\footnotetext{
${ }^{35}$ Art. $5^{\circ}$, X da Constituição da República Federativa do Brasil.

${ }^{36}$ DIAS, Maria Berenice. Separação e Divórcio. Disponível em:

$<$ http://www.mariaberenice.com.br/manager/arq/(cod2_764)10_da_separacao_e_do_divorcio.pdf >. Acesso em: 21 mai. 2019.

${ }^{37}$ Ministro Villas Bôas Cueva coloca que "a supressão dos requisitos para o divórcio pela emenda constitucional não afasta categoricamente a existência de um procedimento judicial ou extrajudicial de separação conjugal, que passou a ser opcional a partir da sua promulgação" em sede do julgamento. BRASIL. Resp 1247098/MS. Recurso Especial 2011/0074787-0/. Relatora Ministra Maria Isabel Gallotti. $4^{\mathrm{a}}$ Turma. Julgamento em: 14/03/2017.

BRASIL. STJ. Disponível em:

<http://www.stj.jus.br/sites/STJ/default/pt_BR/Comunicação/noticias/Not\%C3\%ADcias/Divórcioe-separação-coexistem-no-ordenamento-jur\%C3\%ADdico-mesmo-após-EC-66>. Acesso em: 11 jun. 2019.
} 
contratar advogado e, além da delonga para o desarquivamento do processo, indispensável é a intervenção judicial.

Cumpre esclarecer que a Emenda Constitucional 66, como entende-se aqui, não aboliu o instituto da separação, apenas disciplinou dinâmica diversa para o já existente instituto do divórcio, desconsiderando lapso temporal e imputação de culpa. Tanto é assim, que admite-se separação judicial sem o divórcio e o divórcio sem prévia separação judicial.

A abolição de imputação de culpa no divórcio e a ideia de família plural como espaço de realização social fizeram do Direito das Famílias um excelente cenário para aplicação das Práticas Colaborativas. O histórico lesgilativo conservador das demandas divorcistas dá lugar a um ambiente de maior liberdade nas escolhas existenciais atualmente, considerando que o ordenamento jurídico atual se apresenta mais flexível e receptível ao novo método que se propõe aqui.

Como veremos a seguir, esse modelo privilegia o protagonismo das partes para desenharem a melhor forma possível de reestruturação familiar, respeitando as peculiaridades e demandas de cada casal, entendendo cada família como única e, portanto, merecedora de um atendimento customizado. 


\section{TÍTULO II - AS PRÁTICAS COLABORATIVAS}

\section{Capítulo $1^{\circ}$ - Surgimento das Práticas Colaborativas}

As Práticas Colaborativas surgiram nos anos de 1990 em Minessota, nos Estados Unidos, como criação de Stuart Webb. Advogado especializado em em Família, Stu testemunhou os efeitos nocivos de judicializar conflitos desse teor.

Diante de sua experiência, passou a perceber que, mesmo exercendo sua profissão guidado pelos ditames éticos, não conseguia contribuir para a efetiva solução do problema. Ao contrário, muitas vezes se sentia agente responsável por tornar ainda maior o grau de animosidade do conflito.

No modelo tradicional, Stu observou que as verdadeiras partes no processo de divórcio - esposa e marido - não se comunicavam diretamente, somente por meio de advogados. Não havia engajamento no processo, e sim terceirização do poder decisório a terceiros (Estado, advogados).

Além disso, percebeu que as crianças envolvidas em divórcios litigiosos sofriam com as consequências das inúmeras brigas e dificulmente tinham sua voz levada em consideração no processo.

Depois de 8 anos com contencioso cível e 17 trabalhando especificamente com Famílias em processos litigiosos, Stu relata com tristeza sua insatisfação profissional e desgaste emocional decorrentes da postura adversarial da advocacia que praticava.

Tamanha era sua frustração, que pretendia abandonar por completo a advocacia e se lançar na área da psicologia, momento no qual passou a frequentar cursos e lhe ocorreu que deveria haver uma maneira mais saudável de praticar a advocacia das famílias. É o que relata no trecho do artigo destacado a seguir:

(...) So then I started thinking: If I was willing to ditch my family law practice, maybe I could come up with a way to continue my family law practice by 
developing a model that would allow me to do those parts of my practice I enjoyed and eliminate the rest. I felt that there has to be a better way to help people resolve their divorcing issues ${ }^{38}$.

Vislumbrando a possibilidade de advogar não por famílias, mas pelas famílias, Stu escreveu uma carta ${ }^{39}$ ao Juiz "Sandy" Keith, da Suprema Corte de Minessota. Ciente do interesse do magistrado pela Mediação, Stu quis compartilhar suas reflexões sobre uma possível forma nova de advogar.

Nela, Stu se refere aos casos dos quais participou durante os quais, naturalmente, o acordo foi alcançado de forma criativa, consensual e cujo resultado foi no modelo de benefício mútuo.

But you and I have both experienced, I'm sure, those occasional times, occurring usually by accident, when in the course of attempting to negotiate a family law settlement, we find ourselves in a conference with the opposing counsel, and perhaps the respective clients, where the dynamics were such that in a climate of positive energy, creative alternatives were presented. In that context, everyone contributed to a final settlement that satisfied all concerned---and everyone left the conference feeling high energy, good feelings and satisfaction. More than likely, the possibility for a change in the way the parties related to each other in the future may have greatly increased. As a result, the lawyers may also develop a degree of trust between them that might make future dealings more productive. So my premise has been: why not create this settlement climate deliberately? ${ }^{40}$.

Surgeriu, então, que houvesse um combinado entre as partes para que a negociação seguisse esse modelo, de maneira que os advogados envolvidos

\footnotetext{
${ }^{38}$ Journal of The American Academy of Matrimonial Lawyers - "An AAML Collaborative Law Primer". Tradução livre: "E então eu fiquei pensando: se eu estava disposto a abrir mão da minha prática de advocacia familiar, talvez eu pudesse pensar em algum jeito de continuar praticando direito das famílias desenvolvendo um modelo em que eu pudesse seguir fazendo a parte que eu gostava e eliminando o restante. Eu senti que precisava existir um jeito melhor de ajudar as pessoas a resolver as questões de seus divócios.

39 CARTA de Stuart Webb ao Juiz "Sandy" Keith. Disponível em: $<$ https://abcfamilyblog.wordpress.com/2015/07/04/the-origins-of-collaborative-divorce-stu-webbsletter/>. Acesso em: 20 mai. 2019.

${ }^{40}$ Tradução livre: Você e eu experimentamos, tenho certeza, ocasiões em que, tendo que negociar um acordo em um caso de família, nos encontramos em reunião com o advogado da outra parte e talvez com a outra parte pessoalmente, na qual a dinâmica era de clima positivo e alternativas criativas. Nesse contexto, todos contribuíam para um acordo final satisfatório - e todos saíam da reunião com energia elevada, sentimentos bons e satisfação. Mais que provavelmente, as chances das partes se darem melhor depois dali era bem maior. Como resultado, os advogados poderiam também desenvolver um nível de confiança entre si e fazer com que negociações futuras sejam mais produtivas. Então minha premissa passou a ser: porque não criar deliberadamente esse climna de acordo?
} 
se dedicassem única e exclusivamente a acordos. Nesses casos, Stu os entitulou "profissionais colaborativos".

The understanding would be that if it were determined at any time that the parties could not agree and settlement didn't appear possible, or if for other reasons adversarial court proceedings were likely to be required, the attorneys for both sides would withdraw from the case and the parties would retain new attorneys from there on out to final resolution. I call the attorney in this settlement model a collaborative attorney, practicing in that case collaborative law $\mathbf{4 1}^{\mathbf{1}}$.

Embora tenha sido fácil perceber que ter o acordo como objetivo seria benéfico para negociação entre membros de uma mesma família, a ideia de Stu foi muito além disso. Chegar a um acordo com a ameaça do ajuizamento da ação, pensou ele, necessariamente implicaria animosidade e beligerância entre as partes durante as negociações.

Por isso, parte fundamental e estruturante da Prática Colaborativa criada por Stu, é o pacto por meio do qual os profissionais envolvidos se comprometessem a limitar sua atuação à esfera extrajudicial. Os advogados, então, deveriam se retirar do caso toda vez que as partes não conseguissem chegar a um acordo ou caso existessem peculiaridades que tornassem necessária a tutela do Estado.

A retirada dos profissionais e seu posteiror impedimento para participar, em qualquer aspecto, do processo judicial, muda a atmosfera da negociação e, segundo Stu, representa uma verdadeira "pausa" no conflito para que ele possa ser analisado e tratado de maneira global.

Como será demonstrado mais adiante, a retirada dos profissionais consubstanciada no chamado "Pacto de Não Litigância" é aspecto vital do processo colaborativo. É por meio deste documento que a negociação descrita por Stu, baseada em brainstorming de soluções de benefício mútuo

\footnotetext{
41 Tradução livre: O entendimento é de que se ficasse determinado que, a qualquer momento, as partes não conseguiriam chegar em um acordo ou que medidas judiciais fossem necessárias por qualquer motivo, os advogados de ambas as partes se retirariam do caso e as partes deveriam procurar novos advogados. Eu chamo o advogado nesse modelo de advogado colaborativo, praticando nesse caso, direito colaborativo.
} 
e com postura colaborativa por parte dos advogados e das partes, é viabilizada.

Na referida carta, Stu lista alguns dos benefícios provenientes da resolução de conflitos de maneira colaborativa, como por exemplo o fato de cada parte ser assessorada por um advogado de sua escolha. Isso significa que, independetemente da postura colaborativa e do fato de ambos os profissionais estarem trabalhando para o acordo, existe parcialidade e a defesa dos interesses de cada cliente.

Além disso, sem a ameaça do processo judicial, a transparência é garantida durante todo o processo. As próprias partes, com a ajuda de seus advogados, trazem para a negociação as informações, documentos e comprovantes necessários.

Stu também explica que, mesmo que as partes eventualmente não cheguem ao acordo, elas terão tido as melhores chances tanto com um especialista em acordo quanto com um especialista em litígio, quando posteriormente procurarem novos advogados para litigar no judiciário.

Esta carta é um marco histórico do início das Práticas Colaborativas, pois consubstancia a essência da ideia revolucionária do advogado. O retorno positivo do magistrado fez com que, no dia $1^{\circ}$ de Janeiro de 1990 , Stuart Webb se auto entitulasse Advogado Colaborativo. A partir de então, Stu mudou sua prática completamente e nunca mais litigou.

Ele também convidou o advogado americano Ronald Ousky para ser coatuor de seu livro "O Caminho Colaborativo para o Divórcio" 42 . Esta obra, além de dissiminar a ideia embrionária pelos colegas daquela comunidade, também ajudou a explicar aos clientes de que se tratava o método. Justamente por isso, não é um livro de doutrina jurídica, mas de linguagem acessível,

\footnotetext{
${ }^{42}$ OUSKY, Ronald; WEBB, Stuart. O Caminho Colaborativo para o Divórcio. Publicado Instituto Brasileiro de Práticas Colaborativas. Rio de Janeiro, 2017.
} 
quase lúdica, para incitar a curiosidade e ajudar os clientes a identificarem se o método colaborativo seria ou não o mais adequado para o seu caso.

No início não existiam outros advogados colaborativos. Stu era o único praticando uma advocacia que, por essência, precisa que dois profissionais se comprometam por meio do pacto de não litigância.

Por isso, ele passou a enviar convites aos colegas para participarem do "jogo colaborativo" e se permitirem experimentar esse novo modelo de advocacia. Foi assim que Pauline Tesler, também advogada americana, e Peggy Thompson, psicóloga americana, ambas do Estado da Califórnia, conheceram o processo colaborativo.

Pauline, assim como Stu, advogou litigiosamente na área de família por anos e, pelos mesmos motivos que ele, se interessou pelo novo modelo. Peggy, que trabalhou durante anos com conflitos familiares, percebia também as mazelas deixadas por divórcios litigiosos na dinâmica familiar, principalmente no que diz respeito às crianças.

Por isso, ambas abrançaram a ideia de Stu e foram mais longe. Segundo elas, em seu livro "Divórcio Colaborativo"43, além do Pacto de Não Litigância, a inclusão de uma equipe multidisciplinar deveria ser também o diferencial de uma prática colaborativa.

Introduziram, portanto, a figura do coach (profissional de saúde psicólogo, assistente social, etc), do neutro financeiro (especialista em finanças voltado para solucionar aspectos objetivos do divórcio, como a partilha de bens) e o especialista infantil (profissional responsável por trazer ao processo a voz das crianças envolvidas nesse núcleo familiar).

No modelo criado por Pauline e Peggy a equipe completa, apelidada por elas de "Golden Apple" seria o ideal. Segundo elas, todas as famílias que passam pela transição de um casal conjugal para um casal tão somente

\footnotetext{
${ }^{43}$ TESLER H., Pauline; THOMPSON, Peggy. Divórcio Colaborativo. Publicado pelo Instituto Brasileiro de Práticas Colaborativas no Rio de Janeiro, RJ em 2017.
} 
parental precisariam de 2 advogados colaborativos, 2 coaches, 1 neutro financeiro e 1 especialista infantil, se houver crianças envolvidas.

Por acreditarem na multifatoriedade do conflito, essas profissionais colocam que o divórcio precisa necessariamente ser organizado do ponto de vista legal, financeiro e emocional, de maneira que é preciso atentar para todas essas facetas com o olhar técnico de especialistas de cada área.

Nesse modelo, conforme é feito na Califórnia, os únicos profissionais neutros seriam o responsável pelas finanças e o especialista infantil. Tanto os advogados como os coaches seriam individuais, ou seja, trabalhariam ao lado de seus cliente, com dever de parcialidade.

A partir de então, o Estado da Califórnia passou a adotar o que hoje é chamado de "modelo da equipe completa" que, como se verá adiante, é relativizado em outros lugares inclusive fora dos Estados Unidos.

Por ter sido capitaniado por um advogado de Família, o movimento colaborativo passou a ser muito vinculado à esta matéria. No entanto, conforme esse método foi se dissiminando, ele passou a ser aplicado também em outras áreas do direito, como, por exemplo, para dirimir controvérsias cíveis e empresariais.

A ideia revolucionária de Stu deu origem a Academia Internacional de Práticas Colaborativas $\left(\mathrm{IACP}^{44}\right)$, que define as Práticas Colaborativas como "um processo de resolução de conflitos voluntário, no qual as partes chegam a um acordo sem recorrer ao judiciário” em seus Padrões de Conduta e Ética ${ }^{45}$.

\footnotetext{
44 Página da Academia Internacional de Práticas Colaborativas. IACP. Disponível em: <https://www.collaborativepractice.com>. Acesso em: 23 mai. 2019.

${ }^{45}$ IACP. Cláusula 8 dos Padrões de Conduta e Ética do IACP. Disponível em: <https://docs.wixstatic.com/ugd/9da3b3_9a21e293dcc3486f8ded50665e6b4f3f.pdf〉. Acesso em: 23 mai. 2019.
} 


\section{Capítulo 2o - Práticas Colaborativas No Brasil}

As Práticas Colaborativas foram vencedoras do Prêmio Innovare ${ }^{46}$ no ano de 2013, o que contribuiu muito para sua difusão, aprimoramento e visibilidade no Brasil. $\mathrm{O}$ instituto Innovare tem como objetivo divulgar práticas que contribuam para a melhoria da justiça.

Avaliadas pela Comissão Julgadora do Instituto, que conta com a presença de ministros do STJ e STF, o método foi objeto do reconhecimento, sendo entendido como revolucionário e com potencial enorme de melhorar a justiça brasileira.

A frente desde projeto estavam Olívia Furst, Tania Almeida e Adolfo Braga. Os três foram responsáveis pela elaboração do projeto e pela dissiminação das Práticas nos jornais, mídias digitais e meios acadêmicos.

Olívia Furst, a atual presidente do Instituto Brasileiro de Práticas Colaborativas, além de advogada e mediadora, atua como docente nas capacitações organizadas pelo IBPC com objetivo de treinar advogados, profissionais da saúde, das finanças, assistentes sociais, mediadores e estudantes.

Além disso, atualmente existem diversos Grupos de Estudos ${ }^{47}$ que se reunem mensalmente para discutir e aprofundar os conhecimentos. Esses grupos são abertos e gratuitos e se dedicam à leituras específicas, apresentação de palestras e discussões teóricas acerca das práticas no âmbito familiar, cível e empresarial.

Existem também Grupos de Trabalho, estes limitados aos já capacitados. Essas reuniões, por sua vez, se dedicam a discutir casos práticos,

\footnotetext{
46 Texto do projeto vencedor do prêmio Innovare. PREMIO INOVARE. Disponível em: <https://www.premioinnovare.com.br/praticas/1/praticas-colaborativas-no-direito-de-familia>. Acesso em: 20 mai. 2019.

47 Atualmente os Grupos de Estudos voltados para o Estudo das Práticas no Direito das Famílias encontram-se na OAB (Coordenação Lívia Caetano), no Mediare (Coordenação Natália Winter e Andrea Wakigawa) e na PUC-Rio (Coordenação Comitê de Jovens Profissionais Colaborativos). Já o Grupo de Estudo que se debruça sobre temas cíveis e empresariais acontece no Centro Brasileiro de Mediação e Arbitragem (Coordenação Renata Vilella).
} 
preservando sempre a identidade das partes, funcionando quase que como uma supervisão. A troca de ideias acerca das possíveis abordagens em um caso colaborativo é fundamental, considerando que a multidisciplinariedade é elemento estruturante do processo colaborativo, tanto na prática, quanto na supervisão.

\section{Capítulo 3ำ - Dispositivos do Ordenamento Jurídico Brasileiro}

Entendemos o tempo em que vivemos, do ponto de vista jurídico, como 'A Era do Judiciário'. É assim, porque em nenhum momento da história foi tão noticiado e discutido a atuação dos juízes, inclusive dos Tribunais Superiores, e o encaminhamento dos casos que são judicializados.

Além disso, são notórias as questões relativas a morosidade, baixa efetividade e descrédito do poder judiciário atualmente. Conforme o relatório Justiça em Números ${ }^{48}$ de 2018, elaborado pelo Conselho Nacional de Justiça (CNJ), existe um "total de 80,1 milhões de processos que aguardam uma solução definitiva. Isso significa um incremento de 244 mil casos pendentes em relação a 2016".

O relatório explica ainda que "A tempo do processo baixado no Poder Judiciário é de 1 ano e 5 meses na fase de conhecimento; de 5 anos e 6 meses na fase de execução no $1^{\circ}$ grau de jurisdição, e de 8 meses no $2 o$ grau. $O$ indicador do tempo de baixa apura o tempo efetiva-mente despendido entre o recebimento e o primeiro movimento de baixa do processo em cada fase".

Mesmo depois de solucionada a controvérsia que originou a fase de conhecimento, a fase de execução dos processos na Justiça Federal e na Justiça Estudual apresentam uma média assustadora de 7 anos e 11 meses e 6 anos e 9 meses, respectivamente, para serem terminarem.

\footnotetext{
${ }^{48}$ CNJ. Relatório Justiça em Números. Disponível em: <http://www.cnj.jus.br/files/conteudo/arquivo/2018/09/da64a36ddee693ddf735b9ec03319e84.pdf >. Acesso em: 20 mai. 2019.
} 
Além de morosa, o relatório Justiça em Números revela o enorme custo que o funcionamento da máquina judiciária acarreta para os contribuintes. É R $\$ 411,73$ o valor pago por habitante para que o judiciário funcione como um todo. Isso significa que, mesmo em um processo cujo ingresso seja gratuito, cada um de nós pagamos mais de 400 reais apenas para que o Poder Judiciário funcione e dê conta da enorme quantidade de processos mecionada acima.

Considerando que boa parte destas ações não necessariamente precisam de tutula jurisdicional, somos convidados à reflexão do quanto econominizaríamos no valor per capta se as controvérsias pudessem contar com o encaminhamento adequado, desembaraçando e diminuindo a montanha de processos que nos afoga hoje.

Além disso, é facilmente perceptível que uma diminuição quantitativa dos processos implicaria direta melhora qualitativa quando da análise dos restantes. Isto, porque magistrados teriam tempo e recursos para melhor analisar os casos que efetivamente merecem tutela jurisdicional.

Considerando o acima exposto, o conceito de Sistema Multiportas ${ }^{49}$ passou a ser adotado como um meio de diversificar encaminhamentos que até então seriam indiscriminadamente enviados ao judiciário, causando justamente o que testemunhamos hoje como falta de celeridade e efetividade.

Por meio deste sistema, imaginamos um cenário com diversas portas que representam os vários possíveis encaminhamentos para gestão do conflito. De acordo com a peculiaridade de cada um, algumas portas serão mais adequadas para enfrenta-lo do que outras. Antes da apresentação deste sistema, o cliente só tinha acesso à porta do judiciário. O que se apresenta

\footnotetext{
49 Aptado da tradução do termo "multidoor corthouse" termo utilizado por Frank Sander em seu discurso. THE Causes of Popular Dissatisfaction with the Administration of Justice. Pound Conference de 1976. Disponível em:

<https://law.uoregon.edu/images/uploads/entries/Michael_Moffitt-Before_the_Big_Bang-

The_Making_of_an_ADR_Pioneer.pdf>. Acesso em: 20 mai. 2019.
} 
hoje é uma vasta gama de encaminhamentos possíveis, formando o Sistema mencionado por Frank Sander.

Ciente destas questões emergenciais, o Direito Brasileiro vem se mostrando cada vez mais flexível quando se trata de autonomia da vontade e protagonismo das partes. A coletânea de normas meramente exemplificativas reunidas neste capítulo tem o objetivo de demonstrar que nosso ordenamento jurídico não só aceita a solução consensual de conflitos, como a estimula.

Exemplo claro é a filosofia autocompositiva do Código de Processo Civil $^{50}$ de 2015, que privilegia, em vários artigos os métodos autocompositivos de resolução de conflitos:

Art. 3 Não se excluirá da apreciação jurisdicional ameaça ou lesão a direito.

§ 2o O Estado promoverá, sempre que possível, a solução consensual dos conflitos. § 3o A conciliação, a mediação e outros métodos de solução consensual de conflitos deverão ser estimulados por juízes, advogados, defensores públicos e membros do Ministério Público, inclusive no curso do processo judicial.

A chegada dos chamados Negócios Jurídicos Processuais com a Lei de 2015 é um excelente exemplo de como o protagonismo das partes é hoje entendido como elemento importantíssimo nos processos judiciais.

Art. 190. Versando o processo sobre direitos que admitam autocomposição, é lícito às partes plenamente capazes estipular mudanças no procedimento para ajustá-lo às especificidades da causa e convencionar sobre os seus ônus, poderes, faculdades e deveres processuais, antes ou durante o processo.

Eles corroboram a ideia de que, a depender das partes e do conflito em si, podem existir peculiaridades que sejam melhor tratadas de outra forma, possibilitando as partes de ajustarem o processo conforme melhor the convier. A ideia de que as partes são as pessoas mais qualificadas para tratarem do conflito fica clara, a medida que o mesmo implica a vida delas e que, portanto, elas o conhecem melhor do que um terceiro.

\footnotetext{
${ }^{50}$ BRASIL. Código de Processo Civil de 2015. Disponível em: 〈http://www.planalto.gov.br/ccivil_03/_ato2015-2018/2015/lei/113105.htm〉. Acesso em: 20 mai. 19.
} 
Com o objetivo de resguardar a segurança jurídica de acordos feitos no modelo autocompositivo, os artigos 515 e 725 determinam a natureza extrajudicial do acordo e a possibilidade da sua conversão em título executivo judicial por meio da homologação:

Art. 515. São títulos executivos judiciais, cujo cumprimento dar-se-á de acordo com os artigos previstos neste Título: (...)

III - a decisão homologatória de autocomposição extrajudicial de qualquer natureza;

Art. 725. Processar-se-á na forma estabelecida nesta Seção o pedido de: (...)

VIII - homologação de autocomposição extrajudicial, de qualquer natureza ou valor.

Conforme será demonstrado no Título III do presente trabalho, a aplicação das práticas colaborativas implica cuidado na própria atuação do advogado. Restará amplamente discutido a função social deste profissional, especialmente no Direito das Famílias, a medida que sua conduta influencia diretamente o processo o qual toda a família está ultrapassando (adultos e crianças).

Se faz aqui necessário, portanto, menção ao Código de Ética e Disciplina da Ordem dos Advogados do Brasil ${ }^{51}$. Sua análise revela facilmente como as práticas colaborativas estão de acordo com os ditâmes ideiais de atuação do advogado. A função de defensor da autocomposição pacífica é estabelecida desde o artigo $2^{\circ}$ como se verifica a seguir.

Art. $2^{\circ} \mathrm{O}$ advogado, indispensável à administração da Justiça, é defensor do Estado democrático de direito, da cidadania, da moralidade pública, da Justiça e da paz social, subordinando a atividade do seu Ministério Privado à elevada função pública que exerce.

Os deveres do advogado também revelam princípios como dignidade da profissão e estímulo a conciliação.

Parágrafo único. São deveres do advogado:

${ }^{51}$ OAB. Código de Ética e Disciplina da Ordem dos Advogados do Brasil. Disponível em: <https://www.oab.org.br/visualizador/19/codigo-de-etica-e-disciplina〉. Acesso em: 20 mai. 2019. 
I - preservar, em sua conduta, a honra, a nobreza e a dignidade da profissão, zelando pelo seu caráter de essencialidade e indispensabilidade;

II - atuar com destemor, independência, honestidade, decoro, veracidade, lealdade, dignidade e boa fé; $(\ldots)$

VI - estimular a conciliação entre os litigantes, prevenindo, sempre que possível, a instauração de litígios;

VII - aconselhar o cliente a não ingressar em aventura judicial; (...)

O artigo $8^{\circ}$ do diploma legal aqui comentado, determina que é dever e não faculdade - do advogado informar ao cliente quanto aos riscos de sua pretensão. Estabelece ainda que o advogado deve, mais uma vez, expressamente informar seu cliente as consequências que poderão resultar da demanda.

Art. $8^{\circ} \mathrm{O}$ advogado deve informar o cliente, de forma clara e inequívoca, quanto a eventuais riscos da sua pretensão, e das conseqüências que poderão advir da demanda.

Uma análise sistêmica do Código permite a interpretação de que este dever de adverência ao cliente está também relacionado ao tipo de encaminhamento de que deve ser dado a depender do caso. Leigo, o cliente procura um advogado para tomar uma decisão informada. Esta premissa abarca não só a estratégia jurídica para ajuizamento do processo, mas antes, a necessidade ou não de efetiva demanda judicial.

A medida que o advogado deve "informar o cliente quanto aos riscos de sua pretenção", entende-se, portanto, é dever dele colocar para o cliente quais são as possíveis consequencias do ingresso ao judiciário, como morosidade, incerteza quanto ao investimento financeiro e, principalmente quando tratamos de casos de família, o possível - e provável - desgaste emocional.

A apresentação do Sistema Multiportas ao cliente não é mera opção dos advogados que se identificam com os métodos adequados de solução de conflitos. A informação sobre a variedade de encaminhamentos que as controversias podem ter é dever do advogado, independente de sua inclinação ideológica/jurídica. 
O importante papel de aconselhar como seria a melhor forma de gerir o conflito de acordo com a sua avaliação técnica que, inclusive, é o motivo pelo qual o advogado é procurado, não exclui de maneira nenhuma, a necessidade de informar também que outras opções tem o cliente naquele caso.

Dada a expressividade dessa discussão em meio a comunidade jurídica, dois enunciados nesse sentido foram aprovados na I Jornada "Prevenção e Solução Extrajudicial de Litígios"

Enunciado $\mathbf{n}^{0}$ 55: "O Poder Judiciário e a sociedade civil deverão fomentar a adoção da advocacia colaborativa como prática pública de resolução de conflitos na área do direito de família, de modo que os advogados das partes busquem sempre a atuação conjunta voltada para encontrar um ajuste viável, criativo e que beneficie a todos" - Flavia Oberga Agosto 2016.

Enunciado $\mathbf{n}^{\mathbf{0}}$ 31: "É recomendável a existência de uma advocacia pública colaborativa entre os entes da federação e seus respectivos órgãos públicos, nos casos em que haja interesses públicos conflitantes/divergentes. Nessas hipóteses, União, Estados, Distrito Federal e Municípios poderão celebrar pacto de não propositura de demanda judicial e de solicitação de suspensão das que estiverem propostas com estes, integrando o polo passivo da demanda, para que sejam submetidos à oportunidade de diálogo produtivo e consenso sem interferência jurisdicional." - Leticia Botelho Agosto 2016.

Ambos colocam em cheque tanto a filosofia colaborativa, como o próprio termo, se transformando em marcos legais da aceitação e estímulo do método tanto da resolução de conflitos familiares quanto os relativos a entes públicos.

Finalmente o Conselho Nacional de Justiça editou a Resolução $125^{53}$ no ano de 2010 que tratou especificamente sobre a necessidade de

\footnotetext{
52 I JORNADA de Prevenção e Solução Extrajudicial de Litígios. Disponível em: $<$ https://www.cjf.jus.br/cjf/corregedoria-da-justica-federal/centro-de-estudos-judiciarios1/publicacoes-1/cjf/corregedoria-da-justica-federal/centro-de-estudos-judiciarios-1/prevencao-esolucao-extrajudicial-delitigios/?_authenticator=60c7f30ef0d8002d17dbe298563b6fa2849c6669>. Acesso em: 20 mai. 2019.

53 CNJ. Resolução 125 de 2010. Disponível em <http://www.cnj.jus.br/busca-atosadm?documento=2579>. Acesso em: 21 mai. 2019.
} 
encaminhamento do conflito aos métodos adequados para sua solução. Seu artigo $1^{\circ}$ determina que:

Art. $1^{\circ}$ Fica instituída a Política Judiciária Nacional de tratamento dos conflitos de interesses, tendente a assegurar a todos o direito à solução dos conflitos por meios adequados à sua natureza e peculiaridade.

Essa normativa pode ser entendida como a porta de entrada das práticas colaborativas no ordenamento jurídico brasileiro. Sua edição trouxe à baila uma discussão mundial sobre a escolha entre os termos alternativos ou aqueados quando analisados os meios de solução de controvérsia extrajudiciais.

Entende-se, pelos motivos que serão expostos no próximo capítulo, que o mais apropriado é utilizar o adjetivo "adequados". Não se trata de uma alternativa à judicialização, como meio de solucionar o caos burocrático e moroso que se instalou. Esta não pode ser entendida como a missão altruísta dos métodos extrajudiciais, como a conciliação, mediação, práticas colaborativas ou arbitragem, por exemplo.

Eles são tão somente o conjunto de encaminhamentos que compõe o Sistema Multiportas, por meio do qual um será eleito - preferencialmente pelas partes - não como melhor ou pior em relação aos demais, mas como o mais apropriado para melhor solucionar o impasse. Essa escolha, vale lembrar, é baseada também no que as próprias partes entendem por "melhor solução", considerando os prós e contras de cada método.

Não se pretende aqui, é fundamental esclarecer, recriminar o judiciário. A máquina estatal é muitas vezes necessária e até adequada para alguns casos extremos, que serão indicados mais adiante. Por isso, a opção da judicialização é mais uma porta que compõe o Sistema e que pode - e deve - ser considerada como tal.

Não se pretende, tampouco, impor as Práticas Colaborativas à todos os divorciados. O divórcio colaborativo não é para todos. É preciso analisar 
cuidadosamente se esse, ou qualquer outro, é o método mais adequado para tratar - de maneira global - aquele caso, com aquelas pesssoas.

Somente a partir da apresentação desta vasta gama de possibilidades para resolução do conflito, judiciais e extrajudiciais, é que podemos efetivamente garantir o Acesso à Justiça. Este princípio constitucional ${ }^{54}$, outrora entendido como sinônimo de acesso ao judiciário, hoje é ressignificado para indicar o acesso ao que as partes entendem por justiça em seu caso. $\mathrm{O}$ que, para esclarecer, pode não ser totalmente indiferente ao Estado.

Encaminhar pessoas gripadas diretamente para UTI faria com que doentes que realmente precisem de atenção e tratamento médico intensivos não o conseguissem, tamanha a quantidade de pacientes. Da mesma forma, não faz sentido partirmos da premissa de que toda demanda conflituosa tem que gerar uma ação judicial e, tampouco, de que é essa a melhor forma para que a controvérsia seja dirimida.

Magistrados, promotores servidores, mesmo que muito preparados, naturalmente não dão conta da excessiva e desproporcional quantidade de processos ajuizados. Isso faz com que, além de moroso, o judiciário se torne ineficaz por falta de uma triagem prévia mais minuciosa. Triagem essa, digase, de responsabilidade principalmente dos advogados.

Conclui-se, portanto, que o ordenamento jurídico recepciona e estimula a lógica colaborativa, o que contribuiria para uma melhora do sistema judicial como um todo. O cenário brasileiro revela-se, portanto, propício para a aplicação destas práticas, como veremos a seguir.

\footnotetext{
${ }^{54}$ Constituição da República Federativa do Brasil de 1988: “Art. $5^{\circ}$ Todos são iguais perante a lei, sem distinção de qualquer natureza, garantindo-se aos brasileiros e aos estrangeiros residentes no País a inviolabilidade do direito à vida, à liberdade, à igualdade, à segurança e à propriedade, nos termos seguintes: (...) XXXV - a lei não excluirá da apreciação do Poder Judiciário lesão ou ameaça a direito;
} 


\section{TÍTULO III - DIVÓRCIO COLABORATIVO}

\section{Capítulo $1^{\circ}$ - Aplicação das Práticas Colaborativas ao Divórcio}

A palavra conflito tem, na maioria das vezes, uma conotação negativa. Geralmente a relacionamos com briga, combate, estresse, entre outros sinônimos não mais agradáveis. Morton Deutsh, felizmente, vem colocar em cheque este que parece ser o senso comum quando é este o tema. Em sua obra "The resolution of conflict: constructive and destructive processes" o autor nos presenteia com um raciocínio que, em linhas gerais, é o seguinte:

O conflito não tem, por si só, um caráter positivo ou negativo. O que determina a consequência do evento conflituoso é a maneira por meio da qual ele é gerido. Por isso, é possível que o conflito tenha tanto o que Deutsh chama de potencial destrutivo, quanto um potencial construtivo ${ }^{55}$.

O termo divórcio, por sua vez, também pode nos remeter à um evento triste, desgastante, difícil, amargurado e doloroso. Alguns autores, inclusive, comparam a dor do divórcio ao luto pela perda de um ente querido ${ }^{56}$. Fato é que, profissionais que trabalham com divorciandos estão, sem dúvida, lidando com pessoas em sua pior versão. Trata-se, muito provavelmente, do momento mais difícil da vida adulta.

Aplicando a teoria Deutsh, entretanto, é possível e, inclusive, provável, que a depender da condução deste processo, o divórcio possa revelar seu potencial construtivo. É possível até que este evento deixe de representar um sinônimo de conflito, e passe a ser entendido como um rito de passagem, por meio do qual uma estrutura familiar desfuncional se reconfigura para melhor atender as atuais necessidades de seus componentes.

\footnotetext{
${ }^{55}$ THE resolution of conflict: constructive and destructive processes. New Haven and London: Yale University Press, 1973. p. 1-32; 349-400.

${ }^{56}$ TESLER; THOMPSON, 2017, p. 23.
} 
Tanto é assim que, nas brilhantes palavras de Rodrigo da Cunha Pereira “(...) a gente casa para ser feliz e se divorcia, também, à procura da felicidade ${ }^{, 57}$.

É certo que, quando o assunto é rompimento de relação, existe um estigma que a nossa sociedade herdou do amor romântico, literatura segundo a qual o divórcio passou a ser demonizado. Para além da significação negativa, o divórcio pode ser entendido como um conflito multifatorial. Isto, porque diz respeito ao fim de uma relação que envolveu afeto, expectativas, tristeza, decepção, um projeto de vida marcado pela clássica ambivalência característica das relações humanas. Ao mesclar razão e emoção, o divórcio envolve várias facetas a serem trabalhadas, tanto que o próprio casamento faz com que uma escolha existencial tenha consequências patrimoniais, sucessórias e, possivelmente, parentais.

Para atravessar o processo de divórcio, portanto, é imperativo que as partes tenham ao seu lado profissionais que as acompanhem durante este evento que, com certeza, é desconhecido e marcado por muita insegurança. É nesse cenário que as Práticas Colaborativas representam, enquanto meio adequado de dissolução de vínculos conjugais, uma verdadeira revolução.

O Pacto de Não Litigância, como já colocado, é o coração do método colaborativo. Nele está consubstanciado o compromisso que os advogados assumem como a primeira etapa em um divórcio nesse modelo. $\mathrm{O}$ pacto marca duas das três principais características do método aqui em comento, quais sejam, a (i) não litigância e (ii) a transparência. Por meio deste documento lido, assinado e entendido por todos os envolvidos, os advogados se comprometem a não ir ao judiciário naquele caso, com aquelas partes, a não ser para homologar judicialmente posterior acordo. É também por meio deste documento que o compromisso da transparência fica estabelecida.

\footnotetext{
57 PEREIRA, Rodrigo da Cunha. Divórcio é decorrência natural do casamento por amor. Disponível em: <https://www.conjur.com.br/2012-jul-24/rodrigo-pereira-divorcio-decorrencianatural-casamento-amor >. Acesso em: 21 mai. 2019.
} 
Os profissionais, portanto, passam a estar completa e inteiramente comprometidos com o acordo. Se, eventualmente e por qualquer motivo, não for possível que as partes alcancem esse objetivo, os advogados estarão impedidos de representa-los em um divórcio litigioso judicial. As partes, então, deverão procurar novos advogados.

Faz-se mister expressamente esclarecer que, por conta do Pacto de Não Litigância, somente podemos usar o termo Práticas Colaborativas em casos nos quais existam dois advogados. Um divórcio extrajudicial e consensual conduzido, por exemplo, pela representação única de um advogado comprometido da mesma forma com não adversariedade pode ser o meio mais adequado para gerir esse processo para estas pessoas. Entrentanto, não há que se falar em práticas colaboratias nestes casos. Da mesma forma, dois advogados que adotem posturas colaborativas e que conduzam o processo de acordo com os princípios das Práticas, mas que não assinem o documento, também não poderão chamar o procedimento, por melhor que seja, de prática colaborativa.

Mesmo que possa parecer simples ou leviana a assinatura do Pacto, ela representa o compromisso dos advogados com a não adversariedade e marca o início de uma condução consensual do divórcio. O pacto traduz, portanto, dois lados de uma mesma moeda. Se, para os advogados, é a promessa de não ir para o judiciário e de transparência total dentro da equipe, para os clientes trata-se da opção pela chamada Representação de Escopo Limitado, ou Unbundled Legal Services ${ }^{58}$.

Isso quer dizer que os clientes escolhem, com base na autonomia da vontade, dois advogados que limitam sua atuação à esfera extrajudicial. Apesar de essa parecer característica meramente formal do processo, tratase, na verdade, de uma enorme mudança subjetiva na negociação. Sem a ameça do processo judicial, as partes podem efetivamente "apertar o botão

\footnotetext{
${ }^{58}$ FORREST S., Monsten. Collaborative Divorce Handbook. Jossey-Bass, CA, USA, 2009. p. 60.
} 
de pausa" e decidir, com calma, criatividade e respeito às latentes emoções que os arrebataram, qual será a melhor forma de reorganizar sua família.

A atmosfera acolhedora proporcionada pelo Pacto, faz com que seja criado um ambiente de negociação baseada em interesses e não posições ${ }^{59}$ em que o diálogo possa fluir sem julgamentos. Afinal, toda a tensão característica do contexto judicial inóspito e impessoal mina a criatividade e, consequentemente, a capacidade de chegar a uma solução de benefício mútuo ${ }^{60}$. É em um espaço blindado de ameaças e conduzido pela honestidade e boa fé que acontecem as reuniões durante o processo.

A lógica colaborativa entende que as questões a serem tratadas no divórcio são questões do divórcio em si, e não problemas trazidos por uma ou outra parte. Nesse contexto, portanto, não há que se falar em culpa, mas, ao contrário, em corresponsabilização. A família é analisada como um sistema e, por isso, mesmo comprometidos com os interesses de seus clientes, os advogados colaborativos tem também o papel de ajudar o divorciando a considera-los dentro do cenário familiar global.

Sendo assim, as reuniões no divórcio colaborativo são, em sua maioria, à quatro. Estão quase sempre presentes ambos os advogados e as partes, com exceção de pontuais questões a serem esclarecidas individualmente por cada parte com seu advogado. Essas reuniões individuais podem acarretar posterior esclarecimentos aos outros membros da equipe, por conta da transparência acordada no Pacto. Em outras palavras, trata-se de um procedimento sigiloso no plano externo, no qual toda a negociação é trazida para a privacidade de um escritório. Quando analisamos a performace da equipe, por outro lado, o que conduz as tratativas de acordo no plano interno, é a transparência.

O prinício da transparência é tratado nos Padrões de Conduta e de Ética da Academia Internacional de Práticas Colaborativas, que estabelece

\footnotetext{
${ }^{59}$ FISHER, Roger et al. Como Chegar ao Sim. Ed. Sextante, 2018. p. 63.

${ }^{60}$ Ibid., p. 80.
} 
que "As partes voluntariamente revelam todas as informações relevantes $e$ subanciais à controvérsia a ser decidida". Isso significa que, ao optar por esse método, ambas as partes disponibilizam todos os documentos pertinentes ao divórcio.

Para tanto, os padrões éticos das práticas determinam expressamente que "cada profissional deve obter permissão escrita do(s) seu(s) cliente(s) para compartilhar informações pertinentes ao processo com todos os outros profissionais colaborativos que estejam trabalhando no caso". Mesmo assim, é possível que o cliente divida com o profissional que o assessora matéria sobre a qual ele pede sigilo mesmo dentro da equipe.

Nesses casos, é preciso esclarecer como compatibilizar a transparência característica do processo colaborativo trazida pelo Pacto e o sigilo advogado cliente, estabelecido pelo Código de Ética da Ordem dos Advogados do Brasil $^{61}$ (OAB). Em um divórcio colaborativo, o cliente se obriga a compartilhar informações pertinentes ao processo com toda a equipe, inclusive com a outra parte e seus assessores ${ }^{62}$.

Caso o profissional, advogado ou não, tome conhecimento de que seu cliente está "retendo ou deturpando informações substanciais relativas ao processo colaborativo, ou, de qualquer maneira, está(ão) agindo ou deixando de agir de forma a conscientemente minar ou aproveitar-se indevidamente do processo colaborativo" ${ }^{63}$ deve, desde já, lembra-lo de que sua conduta é contrária aos princípios colaborativos e salientar a importância de todos os esclarecimentos serem feitos no contexto da equipe que apoia as partes.

Se o cliente, depois de advertido, ainda assim não quiser dividir essa informação com a equipe, o advogado colaborativo se retira do caso sem compartilha-la com os colegas de maneira à respeitar o sigilo advogadocliente e, ao mesmo tempo, não violar a transparência. Sua retirada,

\footnotetext{
${ }^{61}$ OAB. Código de Ética e Disciplina da Ordem dos Advogados do Brasil. Acesso em: 20 mai. 2019.

${ }^{62}$ IACP. Cláusula 8 dos Padrões de Conduta e Ética do IACP. Acesso em: 29 mai. 2019.

${ }^{63}$ Ibid., Cláusula 9. Acesso em: 29 mai. 2019.
} 
entretanto, será um indicativo para os profissionais de que existe alguma irregularidade no caso.

Outra situação é aquela em que o cliente divide com o profissional colaborativo informação que não diga respeito e/ou não prejudique o processo, caso no qual a ponderação privilegia o sigilo profissional-cliente em detrimento da transparência. Vale lembrar que esta análise é critério do profissional, de maneira que cabe a ele discernir o que configura ou não questão a ser compartilhada com a equipe.

À título de ilustração, passamos a análise da seguinte situação: o cliente divide com o advogado que possui contas no exterior, mas pede que ele não compartilhe essa informação com a equipe com receio, por exemplo, de que isso crie expectativa de pagamento de alimentos em valor mais alto do que pretende pagar. Esconder deliberadamente esta notícia configura, evidentemente, fraude ao procedimento colaborativo que é pautado pela honestidade e boa fé. Portanto, o advogado deve explicar ao seu cliente o motivo pelo qual a transparência é elemento estruturante deste método e conforta-lo em sua preocupação, o assegurando de que o limite de sua capacidade financeira será respeitando. Insistindo o cliente, demonstrando um perfil efetivamente fraudulento, o advogado tem o dever de se retirar do caso, renunciando a procuração, mas preservando o sigilo da informação fornecida.

Diferente desta é situação em que, por exemplo, o cliente compartilha com o advogado que tem suspeita de possuir uma doença terminal, esclarecendo que ainda não fez todos os exames para confirmar o diagnóstico. Apesar de ser esta informação muito relevante, em nada prejudica, pelo menos não à princípio, o andamento das negociações, motivo pelo qual entende-se que o sigilo pode ser preservado apesar da transparência, se este for o desejo do cliente.

A ambiência é uma das coisas mais importantes neste procedimento, porque, naturalmente, o físico reforça o psicológico. Por isso, as mesas nas 
quais acontecem as reuniões à quatro deverão ser preferencialmente redondas, as partes são encorajadas a sentarem-se uma ao lado da outra, de frente para seus advogados e o desconforto trazido por um passa a ser responsabilidade de todos. A postura dos envolvidos é tão diferente neste modelo que, muitas vezes, é difícil identificar qual dos clientes que contratou qual dos advogados. Os dois profissionais se comunicam com cordialidade e gentileza entre si e com o cliente de seu colega, também respondem qualquer pergunta feita durante a reunião, independentemente de ter sido feita pelo seu cliente ou não.

Por ser um método em que se elimina a possibilidade de judicialização, as partes não podem mais contar com o respaldo de um terceiro, que no modelo tradicional, é representado pelo juiz. Por isso, no divórcio colaborativo as partes são as verdadeiras protagonistas de todas as escolhas, tanto formais como substanciais, que permeiam o procedimento. Elas são a todo tempo encorajadas a falar, argumentar, perguntar, manifestar seus sentimentos e preocupações. Os advogados, como se verá no próximo capítulo, são uma ferramenta através da qual os divorciandos possam tomar decisões informadas.

As Práticas Colaborativas tem a premissa fundamental que as pessoas envolvidas no processo são, por natureza, experts no conflito que estão vivendo. O divórcio, portanto, é entendido como uma consquência da história daquele casal específico, permeada e influenciada por incontáveis variáveis que culminaram no fim do par conjugal. Por isso, da mesma maneira que o casal escreveu a história de amor que regeu o casamento até ali e, portanto, sabem melhor do que ninguém tudo que contribuiu para este desfecho, nada mais lógico que permitir que eles sejam os autores do último capítulo dessa narrativa.

No método tradicional, à título de comparação, delegamos as inegavelmente difíceis decisões para o Estado. Escolher terceirizar esse processo e, nesse sentido, se omitir - já que muitas vezes pode ser doloroso 
demais lidar com a verdadeira montanha-russa ${ }^{64}$ de emoções que representa o divórcio - a princípio pode parecer um alívio. A perigosa consequência, entretanto, é que escolher transferir as deciões para alguém que, por mais competente que seja, não conhece as partes e suas histórias e tem, como já vimos, uma imensa quantidade de processos para dar cabo.

No cenário judicial que temos hoje, ingressar com uma demana significa abrir mão de todo e qualquer controle do tempo despendido, desgaste emocional envolvido, investimento financeiro feito e, principalmente, do resultado final. O magistrado, naturalmente, vai basear sua decisão em fundamentos normativos. A lente jurídica, entretanto, não é a única através da qual o divórcio deve ser analisado, justamente porque, como já vimos, trata-se de um conflito multifatorial. Por isso, mesmo que devidamente embasada na legislação, doutrina e jurisprudência pertinentes, a sentença muito provavelmente não dará conta de tratar, por exemplo, o aspecto emocional que as partes demandam.

Além de tudo isso, não se pode ignorar que o judiciário muitas vezes representa sintomas mais graves do que pura e simplesmente uma briga infindável e ilógica do casal. De acordo com Ricardo Vainer:

O casal, já não suportando o jogo tão intenso de conflito dentro da convivência diária - mas não se sentindo capaz de interrompê-lo -, tenta mantê-lo à distância, pelo sistema do judiciário e pelos advogados, que são representantes instrumentais do conflito, tanto em nível psicodinâmico como judiciário ${ }^{65}$.

O que o autor coloca é que, muitas vezes, o casal passa a triangular com a máquina estatal para seguir se relacionando, mesmo que indiretamente. É através dos tribunais que este par, emocionalmente incapaz de continuar na dinâmica desfuncional do casamento, perpetua o vínculo por meio do litígio.

Cabe aqui a reflexão de que talvez tudo isso represente um preço alto demais para pagar ao escolher indiscriminadamente pela judicialização,

\footnotetext{
${ }^{64}$ TESLER; THOMPSON, 2017, p. 23.

${ }^{65}$ VAINER, Ricardo. Anatomia de um Divórcio Interminável: o litígio como forma de vínculo, uma abordagem interdisciplinar. Ed. Casa do Psicologo, 1999. p. 17.
} 
considerando que não estamos tratanto aqui de uma desavença societária, questão consumerista ou desentendimento civil. A família representa, por natureza, uma rede de relações continuadas, principalmente quando tratamos de um casal que, mesmo divorciado, precisará dialogar para sempre enquanto casal parental.

O protagonismo defendido pelo raciocínio colaborativo, por outro lado, faz com que as pessoas se vejam representadas naquele processo a medida que elas tem a chance de privilegiar o que é mais importante pra elas. Cada divórcio é único, assim como a história de amor que o precedeu, motivo pelo qual estabelecer o que significa reestruturar uma família é muito particular. $\mathrm{O}$ que as partes entendem por justiça, segurança, reconhecimento, bem estar próprios e das crianças, entre outros valores levantados pelo casal, será refletido pelo termo final.

Essa representatividade, não é difícil concluir, faz com que o acordo seja autosusentável no tempo. Isso significa que um combinado feito por duas pessoas nesse modelo tem muito menos chances de ser revisto do que uma decisão imposta por um terceiro, da qual as partes pouco ou nada participaram. É, sem dúvida, um processo emancipatório, tendo em vista que concentra todo o poder decisório nos divorciandos, que, por sua vez, são estimulados e empoderados a tomarem as rédeas e não mais serem infantilizadas diante do paternalismo estatal. Ademais, as partes abandonam a ideia de representação no que tange os advogados e passam a trabalhar numa lógica de parceria, como será desenvolvido no capítulo seguinte.

É o que coloca Marilia Campos Oliveira e Telles:

Ora, se não for dada a oportunidade desta narrativa ao sujeito não só estaremos excluindo-o da conta como estaremos impedindo, negando, tirando, seu papel de protagonista, reduzindo-lhe a zero. Nós, advogados, não queremos mais falar pelos 
nossos clientes, mas queremos estar junto deles, como parceiros, consultores e não representantes! ${ }^{66}$.

Naturalmente, com o privilégio de grandes poderes traz o encargo de igualmente grandes responsabilidades. Imaginamos o quanto pode ser doloroso e duro estar diante de seu cônguje em várias reuniões, sentando lado a lado, dialogando e aceitando que a preocupação e incômodos dele também tem que ser considerados. Muitas vezes o fim do amor é marcado por traições, mentiras, decepções e muito recentimento. O protagonismo pede um engajamento que, neste contexto, pode ser muito custoso. Ressalta-se aqui que nada disso é ignorado pelo processo colaborativo, pelo contrário.

Mesmo com toda essa dificuldade natural e legítima, a proposta do divórcio colaborativo é um convite. As partes escolhem voluntariamente assumir uma postura não adversarial, ainda que de forma custosa. Elas escolhem adotar uma conduta cordial com seu cônjuge e escolhem também um advogado que faça o mesmo, com a garantia de total reciprocidade.

Tudo isso, não porque são evoluídas, superiores ou altruístas as pessoas que escolhem o divórcio colaboratio, mas sim porque objetivamente entendem e desejam usufruir dos inúmeros benefícios trazidos por este método. No cenário aqui proposto, os divorciandos têm maior controle sobre o processo. O tempo não ficará à mercê da morosidade e burocracia judicial; os honorários pagos serão previamente pactuados e computados de acordo com a quantidade de reuniões que cada casal precisará. Nada menos importante é o benefício relativo ao resultado do processo, já que, como explicado, ambas as partes terão contribuído ativamente para os termos finais do acordo não sendo pegas de surpresa e entendendo o caminho percorrido até ali.

\footnotetext{
${ }^{66}$ TELLES, Marília Campos Olveira e. Um Olhar Multidisciplinar sobre o Cuidado na Resolução de Conflitos: Mediação e Práticas Colaborativas. Disponível em: <https://www.linkedin.com/pulse/um-olhar-multidisciplinar-sobre-cuidado-na-resoluçãomar\%C3\%ADlia-campos/>. Acesso em: 22 mai. 2019.
} 
Questões emocionais institucionalmente ignoradas pela dinâmica adversarial do judiciário fazem com que, mesmo depois de ajuizada a ação, o casal ainda conserve o elo que une um ao outro, ainda que pelo intermédio do juiz. Sendo assim, a sentença que põe fim ao processo judicial pode marcar o início do processo de divórcio emocional que não foi reconhecido e/ou tratado até então.

Considerando a importância da análise global do conflito e privilegiando o trabalho multidisciplinar do mesmo, Ricardo Vainer coloca:

O mundo das leis - onde o jargão tão representativo da objetividade da letra da lei reza 'O que não está nos autos do Direito não existe no mundo da Lei' - , nos dá a ideia do recorte da realidade em que tal modelo se baseia. Por outro lado, o universo psicossocial onde o subjetivo é o prisma mais importante da leitura e da construção da realidade, o essencial quase nunca é o que é dito e "o que não existe no discurso" é muitas vezes o que está sendo comunicado ou ouvido ${ }^{67}$.

No paradigma colaborativo as partes podem escolher todas as pautas que serão tratadas durante o processo - tanto objetivas, quanto subjetivas dando conta do conflito como um todo e considerando sua caractarística multifatorial. Sendo assim, as demandas financeiras do divórcio, bem como as emocionais podem ser contempladas totalmente com o trabalho colaborativo.

Isto nos traz para a terceira característica do divórcio colaborativo, depois da não litigância e da transparência, relativa então à multidisciplinariedade. Como mencionado rapidamente no Capítulo $1^{\mathrm{o}}$ do Título II, foram Pauline Tesler e Peggy Thompson as profissionais, advogada e psicóloga, respectivamente, que efetivamente introduziram a ideia de trabalho em equipe multidisciplinar no âmbito do divórcio colaborativo. $\mathrm{O}$ objetivo de compor uma equipe formada por profissionais de saúde, finanças e direito parte do princípio que uma análise monodisciplinar é sempre parcial. Isso quer dizer que, por mais preparado que seja o profissional, ele,

\footnotetext{
${ }^{67}$ VAINER, 1999, p. 18.
} 
naturalmente, irá analisar o conflito de acordo com a sua formação acadêmica e profissional, afinal, é exatamente para isso que ele foi contratado.

É nesse sentido que se posicionam Stuart Webb e Ronald Ousky ao colocar que:

Orientadores do divórcio são membros vitais da equipe. Estimamos que apenas $20 \%$ daquilo com que lidamos em um divórcio são questões jurídicas - os outros $80 \%$ restantes são emocionais. Ter orientadores na equipe permite aos advogados se concentrar naquilo que mais sabemos - o Direito e chegar a acordos mutuamente satisfatórios $^{68}$.

Nesse sentido, pode ser interessante adicionar, além dos advogados colaborativos, profissionais da psicologia para tratar as questões emocionais do casal e das crianças, se houverem, bem como profissionais de finanças, responsáveis pela contabilidade e pelo planejamento financeiro que envolve a partilha de bens.

O papel do psicólogo nesse contexto é restrito a atuação no que tange questões do divórcio, motivo pelo qual ele busca explorar de interesses, expectativas e necessidades das partes, trabalhar perdas afetivas e emocionais ocasionadas pela reestruturação familiar, separar as pessoas do problema ${ }^{69} \mathrm{e}$ facilitar o diálogo e a escuta empática nas negociações. A literatura pertinente ao tema passou a utilizar o termo coach para identificar esse profissional, tanto para deixar claro que existe uma diferença entre sua atuação e a do psicólogo em arendimento clínico, como também para tentar ultrapassar a resistência cultural que alguns tem o tratamento de questões mentais/emocionais.

É necessário deixar claro que, em que pese a visível banalização do termo "coach", utilizamos esta palavra no contexto colaborativo para identificar aqueles que necessariamente tem formação em psicologia e estão atuando como profissionais da saúde no escopo da equipe aqui tratada. Em

\footnotetext{
${ }^{68}$ OUSKY; WEBB, 2017, p. 99.
}

${ }^{69}$ FISHER, 2018, p. 40. 
outras palavras, este profissional deve ser necessariamente psicólogo para atuar como coach em um divórcio colaborativo. Não é possível que outras formações que também atribuam este título viabilizem essa atuação nas práticas colaborativas.

Por meio da figura do coach as partes são convidadas a refletir sobre o futuro pessoal e também a traçar uma divisão clara entre o casal conjugal que está se desfazendo e o casal parental que, apesar de reestruturado, seguirá existindo.

É fundamental esclarecer que não se trata de terapia. Apesar dos coaches terem formação em psicologia, quando inseridos na equipe colaborativa sua atuação é restrita às questões do divórcio. Existe uma pauta a ser trabalhada e as reuniões são desenhadas para dar conta de impasses específicos. Sendo assim, não há que se falar em psicanálise, já que não se pretende tratar questões existencias nesse contexto.

Muito se discute sobre o que a literatura chama de "modelo do coach único". Quando esta figura foi pela primeira vez mencionada na literatura no livro de Stuart Webb e Ronald Ouksy ${ }^{70}$, foi colocado que cada cônjuge teria o seu próprio coach, formando a equipe com quatro profissionais (dois advogados e dois coaches):

Orientadores colaborativos, ou orientadores do divórcio, são profissionais formados em saúde mental que estão ali para ajudar os cônjuges (cada um deles tem seu próprio orientador) a lidar com questões emocionais e psicológicas que, do contrário, podem prejudicar o processo de conseguir um acordo.

A medida que o método colaborativo se dissiminou, nos deparamos com inúmeras releituras da equipe tradicional proposta por Stuart Webb e Pauline Tesler. Em diferentes comunidades por todo o mundo, notamos ser mais comum a figura do coach único, seja porque as partes acreditam que uma abordagem psicológica imparcial pode ser mais benéfica (e, nesses casos, recomenda-se profissional com formação em terapia sistêmica), seja

\footnotetext{
${ }^{70}$ OUSKY; WEBB, 2017, p. 99.
} 
porque se pretende diminuir os gastos com a equipe. Qualquer que seja o motivo, é interessante notar que trata-se de um movimento metacolaborativo, a medida que cada profissional incrementa o modelo primário como melhor atender seus clientes. Cada região terá sua preferência por um modelo de prática colaborativa que se revela baseado nos pioneiros deste método naquela comunidade.

O coach também pode ter a função fundamental de indicar, quando achar pertinente, o chamado especialista infanto juvenil ou coach infantil. Em que pese esta poder ser uma demanda inicial dos divorciados, o profissional da saúde que os atenda também pode recomendar e até indicar outro profissional cuja função será trazer a voz da criança para o processo. Diferente do que muitas vezes testemunhamos no modelo tradicional, o divórcio colaborativo não expõe os filhos ao lugar impessoal e frio que representa o judiciário em um momento tão delicado. Ao contrário, a escuta é feita por meio de profissionais especializados, em consultórios preparados para tanto.

Seu trabalho é identificar as necessidades emocionais e preocupação dos filhos, temas que deverão ser considerados pelos pais e pela equipe colaborativa; ajudar os pais na identificação de aspectos relevantes do momento de vida das crianças, considerando as mudanças da dinâmica familiar sob sua perspectiva. Em outras palavras, o coach infantil será o porta-voz da criança para ajudar os pais a entendem o que o divórcio significa para ela e quais são as suas demandas na transição pela qual a família está passando.

Mais uma vez a literatura nos esclarece pontos importantes, já que o primeiro livro escrito sobre o tema já colocava que:

(...) O especialista faz recomendações aos pais para ajuda-los a entender estágios de desenvolvimento infantil e desenvolver um plano de criação viável. Na nossa 
experiência, este é o único processo de divórcio que dá voz aos filhos na definição dos planos - ou mesmo uma chance de que sejam ouvidos de forma significativa ${ }^{71}$.

Também é uma possibilidade contratar Especialistas Financeiros para compor a equipe multidisciplinar aqui tratada. Se for essa a escolha das partes, esclarece Webb e Ousky que eles:

\begin{abstract}
São membros neutros da equipe cuja função é ajudar você (o cliente) e seus advogados a reunir, organizar, analisar e compreender sua situação financeira e as várias opções que ela oferece. Um típico especialista financeiro, que integra a equipe colaborativa, é especializado em determinar patrimônio e orçamento pessoal, identificar leis fiscais e relevantes para as situações das partes, trabalhar com questões de pensões, valor de propriedade e preocupações com fluxo de caixa. Ele irá orientá-los sobre questões monetárias e, com a aprovação das duas pessoas, pode se encontrar com vocês separadamente caso precise de mais orientação sobre questões financeiras básicas $(\ldots)^{72}$.
\end{abstract}

Diferentemente da figura do coach, que pode ser representada por dois profissionais ou que pode ser único e, só nesta última hipótese, imparcial, o especialista financeiro é necessariamente único. Portanto, ele está comprometido com o processo e não guarda vínculo com nenhuma das partes. Por isso, pode ser interessante, muito embora no Brasil não seja um pré requisito $^{73}$, que ele tenha alguma formação em mediação para fazer uso de suas ferramentas na construção do diálogo já que ele pode ser o único membro neutro da equipe.

Além desses profissionais, pode ser que os divorciandos tenham demandas específicas que criem a necessidade de adicionar outros experts à equipe. Se o casal for, por exemplo, proprietário de uma empresa que precise dividir cotas no momento da partilha, talvez seja interessante chamar ao processo um especialista em avaliação de ativos. Se, por outro lado, trata-se de uma família com vasto patrimônio imobiliário, um corretor pode ser

\footnotetext{
${ }^{71}$ OUSKY; WEBB, 2017, p. 100.

72 Ibid., p. 100.

${ }^{73}$ O Instituto Brasileiro de Práticas Colaborativas não é um órgão regulador, tampouco fiscalizador. Entretanto, tanto é verdade os benefícios que a formação em mediação traz para o profissional colaborativo, que as Capacitações em Práticas Colaborativas ensinam algumas ferramentas para auxiliarem o profissional atuando em um divórcio colaborativo.
} 
contratado para auxiliar na avaliação dos imóveis. Essas pessoas também terão o dever de neutralidade em relação às partes, como ocorre com o Especilista Financeiro, e isso se deve ao seguinte raciocínio:

Por que a neturalidade é importante? Isso é mais bem explicando avaliando o que costuma acontecer em litígios quando surge uma questão que demanda a opinião de um especialista externo. O que costuma acontecer nesse caso é que cada parte contrata seu próprio especialista para dar uma opinião. $\mathrm{O}$ resultado é mais polarização, com os especialistas tendendo a distorcer suas opinões para favorecer o ponto de vista de seu cliente (que, claro, os está remunerando) ${ }^{74}$.

Sendo o divórcio, como já vimos, um evento complexo, sua apreciação somente por meio da lente jurídica, como ocorre no modelo tradicional, pode ser parcial e limitada, por mais qualificado que seja o advogado. Essa análise monodisciplinar pode implicar exame de questões relativas à saúde emocional ou financeira por parte do advogado que, mesmo especialista em Direito das Famílias e acostumado com pauta subjetiva e partilha de bens, não encontra em sua formação subsídio para fazer deste o seu lugar de fala. Conferir ao profissional de direito atribuições inerentes aos profissionais da saúde ou ao especialista financeiro significa demorar mais tempo (tornando os honorários advocatícios mais altos), para entregar um resultado incompleto, já que não é esta, afinal, a sua área.

Assim como os advogados, os coaches - dos adultos ou das crianças -, os especialistas financeiros e outros possíveis experts que porventuram componham a equipe estão abarcados pela transparência e não litigância. Isso significa que haverão reuniões de equipe cujo objetivo será dividir o que cada profissional observou no caso, por meio de suas diferentes lentes, possibilitando a ideal análise multifatorial. Se eventualmente o acordo não for possível, todos os profissionais também devem se retirar e estão protegidos pelo sigilo, não tendo que testemunhar ou fornecer material probatório em sede de litígio judicial.

\footnotetext{
${ }^{74}$ OUSKY; WEBB, 2017, p. 102.
} 
Trata-se, enfim, de um processo muito costumizado. Cada casal e sua história vão determinar as demandas que precisarão ser atendidas no momento do divórcio e, consequentemente, quem são os profissionais adequados para compor a equipe que irá assessora-los. Inclusive, porque cada profissional cobrará seus honorários independentemente da equipe. Por isso, o orçamento destinado ao divórcio também é algo a ser discutido pelo casal. Nesse sentido, se faz necessário aqui um esclarecimento acerca da multidisciplinariedade tratada acima.

Ronald Ousky, um dos pioneiros e atual líder global do Movimento Colaborativo, em seu artigo sabiamente entitulado "Developing a Range of Collaborative Models: One Size Does Not Fit All"75 critica, com razão, o que gostamos de identificar como o "mito da equipe completa". Ron compara a doutrina que prega a equipe completa como requisito e elemento estruturante do divórcio colaborativo com as lojas que vendem vestuário tamanho único. Nesse sentido, da mesma forma que consumidores tem diferentes anatomias que demandam variações mínimas como tamanhos $\mathrm{P}, \mathrm{M}$ e $\mathrm{G}$, muito mais razão tem divorciados que precisam da liberdade de desenhar suas próprias equipes, de acordo com as peculiaridades de seu próprio divórcio.

Cada história de amor é única, logo, entendemos hoje que a família, espaço de realização existencial, originada deste afeto ímpar é espaço de expressão das particularidades existenciais de cada um. Sabendo que o divórcio é o final desta narrativa singular, por que o processo colaborativo seria generalista a ponto de impor a formação de uma equipe baseada em suposições do que as partes precisam?

Ousky vai além neste raciocínio ao colocar que não só faz parte da autonomia da vontade decidir quem serão os assessores do casal, mas também em que medida eles estarão envolvidos no procedimento:

\footnotetext{
${ }^{75}$ MOSTEN, S. Forrest; CORDOVER B., Adam. Bulding a Successful Collaborative Family Law Practice. Ed. ABA Section of Family Law, 2017. p. 120-121.
} 
The ideal Collaborative model is the one that can adapt to the need of each family - not only in the selection of the team members, but in the degree to which team member is engaged $^{76}$.

Partindo do princípio de que, sendo um divórcio, os advogados sempre serão incluídos, o autor advogado salienta de antemão que pode parecer parcial defender a composição mais flexível da equipe. Entretanto, não é isso que ele sugere:

Indeed, as the prior examples show, we are increasingly finding that, in a carefully designed Collaborative team case, the attorneys can be excluded from many of the meetings (or portions of the meetings), thus freeing up resources for the clients to work with the mental health professionals or financial neutrals ${ }^{77}$.

Considerada a Alfaiataria do Direito como referência a customização do procedimento colaborativo, as Práticas defendem a importância do estudo casuístico pelos advogados no que tange o encaminhamento para método mais adequado, e pelos clientes no que diz respeito a composição da equipe sempre que a opção for pelo divórico neste modelo.

A respeito desta análise casuística feita por parte do advogado, muito se discute sobre a possibilidade ou não do emprego das práticas colaborativas quando o divórcio envolve abuso de alcool/drogas ou violência doméstica. A atuação dos advogados dentro do escritório sem a tutela do Estado quando encontramos situações como essa pode ser questionada.

Nesse sentido, se posiciona Pauline Tesler ao colocar:

O divórcio colaborativo pode não ser uma boa escolha, quando:

- Um ou ambos os cônjuges têm grave distúrbio mental ou problemas com álcool ou drogas que não estejam sob controle;

- Está ocorrendo violência doméstica;

\footnotetext{
76 Tradução livre: O modelo colaborativo ideal é aquele que pode ser adaptado de acordo com a necessidade de cada família - não somente no que se refere a seleção dos membros da equipe, mas também na medida em que cada membro estará envolvido.

77 Tradução livre: Na verdade, como exemplos anteriores monstram, estamos cada vez mais descobrindo que, em um caso colaborativo com uma equipe cuidadosamente escolhida, os advogados podem ser excluídos de várias reuniões (ou fragmentos das reuniões), consequentemente liberando recursos para clientes trabalharem com profissionais da saúde ou profissionais de finanças.
} 
- Um ou ambos os cônjuges não tem capacidade de assumir ou manter compromissos firmados, mesmo com a ajuda dos coaches em divócrio colaborativo;

- Um ou ambos os cônjuges estão pre dispostos a mentir de modo a esconder infromações financeiras ${ }^{78}$.

O que a Autora coloca, de forma muio pertinente, é que por maior que seja nossa insegurança em empregar um processo caracterizado pela extrajudicialidade nesses casos, talvez sejam essas as ocasiões em que ele seja mais necessário.

Certamente, nenhuma outra forma de divórcio tampouco lida com esses desafios de modo eficiente. (...) É você (o cliente) quem decide se prefere estar em um divórcio adversarial, que tende a aflorar o pior das pessoas, ou se prefere um divórcio colaborativo, que ao menos tentará trazer à tona o melhor das pessoas, tal como já funcionou com tantas outras ${ }^{79}$.

Infelizmente é comum testemunhar términos de relação marcados por abusos, violência, adição, compulsão. No modelo tradicional, essas questões naturalmente aparecem em um processo judicial e são tratadas da maneira que é possível para o Estado. Isso significa morosidade, ineficiência e análise jurídica de demandas emocionais, como já vimos.

Isso quer dizer que, por mais que seja contra intuitvo cuidar desses casos com uma postura conciliatória e autocompositiva, será que judicializar essas questões realmente é mais benéfico? Ou seria mais prudente e cuidadoso endereçar esse sistema familiar, que enfrenta tantos desafios, à advogados colaborativos com formação especializada em diálogo e negociação pacífica e à uma equipe multidisciplinar composta especificamente para atendê-los?

O objetivo deste trabalho não é, como inclusive já foi colocado, impor o modelo colaborativo a todos os divorciandos. Com base no protagonismo, na autonomia da vontade e sendo corretamente informados a respeito do que se trata, cabe a eles próprios estabelecer se é ou não o caso de fazer uso desse

\footnotetext{
${ }^{78}$ TESLER; THOMPSON, 2017, p. 47.

${ }^{79}$ Ibid., p. 47.
} 
método. Essa escolha é feita com base da ponderação das características das Práticas tratadas aqui, em comparação com estrutura do divórcio tradicional.

Por isso, se justamente as partes desafiadas pelas questões citadas por Pauline, enquanto experts nesse conflito, entenderem o processo colaborativo como o mais adequado para atendê-los, é difícil vislumbrar qualquer impedimento. Afinal, como já vimos, trata-se de um procedimento marcado pelo cuidado, atenção e respeito. Tudo que só tem a beneficiar um sistema familiar em crise, principalmente nesses casos.

Considerando todas as reflexões deste capítulo, é necessário convidar ao questionamento do que tange o papel do advogado no cenário colaborativo. A responsabilidade deste profissional é revista no modelo aqui proposto, fazendo com que sua atuação passe a ser totalmente diferente do modelo tradicional.

\section{Capítulo 2으 - O Resgate do Paradigma do Advogado das Famílias}

A maioria esmagadora da doutrina que embasa esta monografia insiste na importância do comprometimento com a "mudança de paradigma" por parte dos profissionais colaborativos. Este tópico, ao qual foi dedicado o presente capítulo, se refere a todos os membros que compõe a equipe, independemente de sua formação de origem. A presente discussão, no entanto, abarcará somente os advogados. Isto, não só por ser este um trabalho jurídico, mas também por serem estes os profissionais para os quais pode ser mais desafiadora a tarefa aqui tratada.

Julie MacFarlane, em sua obra "The New Lawyer: How Settlement is Transforming the Practice of $\operatorname{Law}^{80}$ " questiona vários dos preceitos tradicionais da profissão advocatícia, defendendo basicamente que o

\footnotetext{
${ }^{80}$ MACFARLANE, Julie. The New Lawyer: How Settlement is Transforming the Practice of Law. Canadá: Ed. UBC Press, 2008.
} 
mercado mudou, a expectativa dos clientes e da sociedade é outra e que, portanto, a formação do advogado deve evoluir para atendê-la.

Segundo Julie, para que essa cultura jurídica efetivamente se transforme é necessário mudar o que ela chama de "normas de legitimidade", que basicamente significa redefedir o que é um bom advogado:

\begin{abstract}
Are they classic zealous advocates, who leave negotiation until the last minute, advocate positionally as long as possible, and assert right-based arguments until final "compromise" is reached on the courthouse steps? Are the "good lawyers" of law school mythology, who spend every day in appeals court arguing obscure points of law? Or are good lawyers those who see themselvs as conflict resolvers, providing efficient, realistic, principled and humane dispute resolution with constructive and practicable result ${ }^{81}$.
\end{abstract}

No raciocínio da autoria exitem três pilares básicos que diferenciam o antigo advogado do novo. O primeiro é referente à ampliação e evolução das habilidades de negociação ${ }^{82}$. O novo advogado é aquele que pode negociar com base em interesses, orientando o cliente a encaminhar o conflito de maneira adequada por meio da apresentação do Sistema Multiportas, e não cedendo à sedução da barganha ou aventuras judiciais indiscriminadas.

O novo advogado também possui ferramentas de comunicação ${ }^{83}$ à sua diposição, como a habilidade de escuta ativa, explicação didática, estabelecimento de rapport e empatia. O terceiro e último pilar que completa o novo advogado, segundo Julie, é a ressiginificação da sua relação com o cliente. No modelo tradicional, o advogado é representante. O novo advogado, entretanto, estabelece uma relação horizontal de parceria com seu cliente, possibilitando o protagonismo de uma tomada de decisão informada.

\footnotetext{
${ }^{81}$ MACFARLANE, 2008, p. 19. Tradução livre: São eles os clássicos advogados mesquinhos, que deixam as negociações para o último minuto, advogam com base em posições ao máximo, são assertivos com uma argumentos baseados em direitos até que o comprometimento seja alcançado nos degraus do tribunal? São os "bons advogados" aqueles da mitologia da faculdade de direito, que ficam todos os dias nos tribunais discutindo pontos obscuros da lei? Ou são os bons advogados aqueles que se vêem como resolutores de conflito, proporcionando a resolução do conflito construtiva e prática com eficiência, de maneira realista e humana, baseada em princípios?

${ }^{82}$ Ibid., p. 23.

${ }^{83}$ Ibid., p. 23.
} 
É evidente a relação estabelecida entre as características descritas e a filosofia colaborativa. O advogado colaborativo É o novo advogado, motivo pelo qual a reflexão tratada neste capítulo se baseia na obra da referida autora.

No paradigma adversarial, o advogado de família tradicional recebe uma das partes que lhe conta, com as emoções à flor da pele, uma versão unilateral da história que o levou até ali. O profissional, então, por meio de sua lente jurídica parcial, cristaliza a narrativa ${ }^{84}$ - naturalmente contaminada de sentimentos - em uma petição inicial que dará o tom de todo o processo dali por diante. Isto, sem falar em profissionais que carregam as tintas para pintar do seu cliente "a vítima" e da outra parte (chamada, não por coincidência, ex adverso) o "vilão".

Nesse sentido se posiciona Julie, ao colocar que:

This means that the lawyer assumes the client's permission to refashion the story in a way that makes it more likely to be successful in a legal-adjudicative framework, emphasizing certain details and overlooking others. Anything that is irrelevant to a legal problem-solving approach - for example, hurt feelings, business practices, or future business dealings - is set to one side ${ }^{85}$.

As emoções e, portanto, as histórias que as refletem, são dinâmicas. Nós nunca contamos a mesma coisa da mesma forma, considerando que nossa versão de nós mesmos naquele dia, pode ser totalmente diferente do dia seguinte. No contexto do divórcio isto é gritante, já que somos arrebatados pela montanha-russa de emoções já mencionada. Por isso, pode ser extremamente violador reduzir o momentâneo relato do cliente à um documento que torna estática memórias permeadas por incontáveis versões e instáveis sentimentos.

\footnotetext{
${ }^{84}$ MACFARLANE, 2008, p. 128.

${ }^{85}$ Ibid., p. 128. Tradução livre: Isso significa que o advogado assume que tem a permissão do cliente para refazer sua história de maneira que ela se torne mais benéfica de acordo com o enquadramento legal, enfatizando detalhes e negligenciando outros. Qualquer coisa que seja irrelevante do ponto de vista legal, por exemplo mágoas, práticas empresariais ou negócios, é colocado de lado.
} 
É por isso que, segundo George Bernard Shaw:

O único homem que se comporta de forma sensata é meu alfaiate. Ele tira minhas medidas novas todas as vezes que me vê, enquanto todos os outros continuam com suas medidas velhas e esperam que eu caiba nelas.

O novo advogado, no paradigma colaborativo, deve se comportar exatamente como o alfaite, checando a cada reunião como seu cliente está, assumindo uma postura curiosa e constantemente reavaliando como é a melhor forma de atender aos seus interesses.

Por muito tempo, o ego dos advogados se acostumou com o papel protetor - quase paternal - de representar o cliente, literalmente falando por ele ${ }^{86}$. Isso fazia algum sentido em um contexto no qual o cliente, consumidor do serviço advocatício, não tinha absolutamente nenhum acesso ao conhecimento jurídico que somente o advogado possuia depois de frequentar a faculdade. Isso tornava essa relação profissional muito verticalizada/desequilibrada ${ }^{87}$, de maneira que a parte não tinha outra alternativa se não delegar o poder descisório totalmente ao advogado confiando que ele o representaria ${ }^{88}$.

No paradigma tradicional, essa postura acarreta a tercerização da responsabilidade pelo processo ao advogado e da responsabilidade sob o resultado ao magistrado, como já visto anteriormente. A consequência trágica é a nítida infantilização do cliente.

O cenário que se apresenta hoje, no entanto, é muito diferente. É comum que os clientes pesquisem seus casos na internet, encontrem teses que suportem seus argumentos e até reúnam jurisprudência favorável ao direito que pretendem. Isso tudo antes mesmo da primeira reunião com o advogado.

\footnotetext{
${ }^{86}$ Julie MacFarlane esclarece que a origem a palavra cliente "can be tracked back to a Latin verb that refers to the right of a Roman aristocrat to impose his own name on this slaves" MACFARLANE, 2008, p. 126.

${ }^{87}$ Ibid., p. 129.

${ }^{88}$ Ibid., 2008, p. 126.
} 
Os meios de difusão de informação, em certa medida, democratizaram o saber jurídico, possibilitando aos clientes empoderamento nesse sentido ${ }^{89}$.

A medida que estes ocupam um lugar mais equilibrado na relação com o profissional, essa dinâmica passa a ser mais horizontal, permitindo que o antigo conceito de representação, passe a dar lugar à ideia de parceria ${ }^{90}$. O cliente, entendido como expert do seu próprio conflito, indica ao advogado suas principais preocupações e expectativas e, com a assessoria técnica do profissional, toma decisões informadas para excercer plenamente seu protagonismo.

Isso não significa, de maneira nenhuma, que o advogado passe a ser menos importante na lógica colaborativa ${ }^{91}$. O que se coloca aqui é imperativa mudança de conduta, postura e atuação do profissional. Se antes ele defendia indiscriminadamente a tese jurídica mais forte, com os melhores argumentos técnicos, agora ele passa a estar a serviço do que é mais importante para o cliente, respeitando o que quer que isso signifique ${ }^{92}$.

É claro que esta nova postura, como toda mudança, gera receio e resistência. Litigar é o que quase todos os advogados tem feito durante toda sua carreira, é o que eles sabem e se sentem confortáveis em fazer, é o que eles aprenderam, é o que os sustentou e os celebrizou até agora.

A postura colaborativa que se defende aqui também é contra intuitiva e definitivamente não conta com apoio social. Agir cordialmente com o cliente e advogado da outra parte pode parecer fraqueza, afinal muitas vezes os clientes procuram os advogados mais carrascos e impiedosos para defendê-los e representar o papel do "salvador" na dinâmica maniqueísta de vítima e vilão descrita acima.

Portanto, a passagem para o paradigma colaborativo requer a desconstrução de uma série de hábitos adversariais que advogados com anos

\footnotetext{
${ }^{89}$ MACFARLANE, 2008, p. 130.

${ }^{90}$ Ibid., p. 125.

${ }^{91}$ Ibid., p. 142.

${ }^{92}$ Ibid., p. 143.
} 
de carreira adquiriram. Requer também que o profissional, tão acostumado a ser absolutamente necessário em todas as fases do processo, abra mão de todo esse controle e ceda seu lugar sob os holofotes ao cliente, a pessoa verdadeiramente legitimada para tomar as decisões relativas à sua vida. Afinal, é ela quem vai conviver com as consequências.

Em tempos nos quais se faz necessário dizer o óbvio, resslata-se aqui que essa postura colaborativa é ainda mais urgente quando tratamos de questões familiares. Quando o direito se mistura com o afeto, se faz mister o olhar sensível do advogado enquanto profissional que, ao invés de inflamar o conflito (ganhando, diga-se de passagem, honorários sobre a perpetuação do ltígio), resolve efetivamente a questão.

Como toda mudança de cultura, principalmente as que desafiam os padrões tradicionais, a militância colaborativa precisa estar estruturada no sistema educacional. O que MacFarlane indica em sua pesquisa é que vários os alunos entram nas faculdades de direito com objetivos humanistas e altruístas, e que isso se perde rapidamente conforme os créditos são cursados $^{93}$. O aparente glamour do advogado litigante pelo qual somos arrebatados durante o curso e por meio de filmes, seriados e livros, induz o pensamento de que não só existe existe recompensa pelo comportamento adversarial, como também de que é esse o papel do advogado.

Nesse sentido, para um curso que tanto promove a capacidade de problematização, pouco se questiona seu papel no tipo de advocacia que está formando ${ }^{94}$. Isso resulta uma longa tradição de postura belicosa por parte desses profisisonais que, inclusive, são estigmatizados pela sociedade que desenha o esteriotipo de advogado como alguém autoritário, bravo e agressivo $^{95}$.

\footnotetext{
${ }^{93}$ MACFARLANE, 2008, p. 31.

${ }^{94}$ Ibid., p. 16.

95 Ibid., p. 26.
} 
Isso acontece principalmente porque, por enquanto, o que os alunos aprendem nas faculdades de direito é brigar ${ }^{96}$. Mesmo quando alguma matéria aborda a resolução consensual do conflito, ela é uma eletiva e é precedida por vários semestres voltados para o processo ${ }^{97}$. A relação com o cliente também não é, em momento nenhum, abordada pelo paradigma educacional adversarial ${ }^{98}$. Esse muitas vezes é tratado inclusive como "o inimigo" que "atrapalha" a atuação objetiva do advogado, por distra-lo com suas questões "menos importantes" 99.

Não pode ser este o olhar com o qual estamos formando jovens advogados, principalmente os que atuarão no Direito das Famílias. Sua responsabilidade é tão grande que, arriscamos aqui colocar, depende de uma formação paralela em certa medida. Formação esta que, mesmo dentro da faculdade de direito, trate de assustos de psicologia, comunicação, negociação e, principalmente, o exercício da empatia. Esta formação multidisciplinar que se propõe aqui é, inclusive, propícia ao ambiente universitário, que abriga diversos cursos em um mesmo espaço.

Ao contrário, a realidade que temos hoje é de advogados especialistas em processo, estratégias, qualificações jurídicas sem fim que, mesmo que indispensáveis, se tornarão obsoletas quando da promulgação de novas leis, mudanças imprevisíveis de jurisprudência e, principalmente, por não abarcarem o fator humano básico e primordial. Com a eminência das novas tecnologias invadindo os escritórios então, logo funções mais mecânicas e burocráticas serão delegadas à inteligência artificial como já acontece em vários cenários.

\footnotetext{
${ }^{96}$ MACFARLANE, 2008, p. 27.

${ }^{97}$ PUC-Rio. Disponível em: <https://www.puc-rio.br/ensinopesq/ccg/direito.html>. Acesso em: 11 jun. 2019.

${ }^{98}$ MACFARLANE, op. cit., p. 125.

${ }^{99}$ Ibid., p. 127.
} 
Por isso e por tudo que já foi exposto, cada vez mais o consumidor deste serviço esperará uma conduta mais humanizada, um olhar mais afetivo e uma atenção mais cuidadosa por parte do profissional.

O novo advogado é aquele que atua principalmente de forma preventiva ao ajuizamento de ações, garantindo que a demanda conflituosa seja gerida da melhor maneira antes mesmo de chegar aos tribunais, entendendo a judicialização como última ratio. Esse é o entendimento não só da doutrina colaborativa, mas também do Ministro do Supremo Tribunal Federal Luis Roberto Barroso, que esclareceu "O advogado do futuro não é aquele que propõe uma boa demanda, mas aquele que a evita"100.

Os profisisonais do futuro, incluindo o novo advogado tratado aqui, entende ser o exercício da profissão um meio de satisfação pessoal, a maneira pela qual ele pode efetivamente ver a pequena mudança positiva que faz na sociedade ${ }^{101}$. Isso é facilmente perceptível quando analisamos os enormes avanços trazidos pela chamada geração millennial no que tange as mais variadas expressões notórias da cultura do cuidado (como a reciclagem na economia, reutilização na moda e práticas colaborativas no direito). A lente através da qual enxergamos o mundo em que vivemos é colaborativa, e isto transcende o universo jurídico.

Tratando de uma geração extrememante influenciada pela tecnologia, celeridade, controle e customização são as palavras que estão na ordem do dia. Por isso, dificulmente teremos aderência a um processo em que não se tem nada disso, como já foi demonstrado que ocorre no judiciário. Sendo assim, a nova geração contribuirá não só para a formação do novo advogado, mas também do novo cliente, aquele que escolhe a responsabilização ao invés

\footnotetext{
100 Palestra dada pelo Ministro Luis Roberto Barroso em 11/08/2018 no Dia do Advogado, no $7^{\circ}$ Congresso Brasileiro de Sociedades de Advogados, promovido pelo Sindicato das Sociedades de Advogados dos estados de São Paulo e Rio de Janeiro (Sinsa) na capital paulista.

SINSA. Disponível em: <https://www.conjur.com.br/2016-ago-12/advocacia-devera-evitardemandas-nao-propo-las-barroso?fbclid=IwAR3EHUVjXTxvgwXyj9zzi9Z6C7NAUCddgxCDhFxw-7zObrxdtbvfKxGguw>. Acesso em: 30 mai. 2019.

${ }^{101}$ MACFARLANE, 2008, p. 141.
} 
da infantilização e o controle e celeridade ao invés da tercerização e burocracia $^{102}$.

Nesse sentido, é extremamente benéfico engajar cada vez mais jovens advogados ao movimento colaborativo. Afinal, além de possuírem as características acima citadas, eles não contam com anos e anos de carreira litigiosa que precedeu à transição para o paradigma colaborativo, pelo contrário. Quando os profisisonais são recém formados, estamos diante de um verdadeiro resgate do paradigma, a medida que eles irão passar a exercer sua profissão de acordo com os ditâmes da sua ideia de sucesso, realização e propósito.

Por isso, defende-se aqui, além da atuação multidisciplinar no que tange as diferentes áreas do saber já citada, a atuação multigeracional como forma de me tornar a equipe mais diversificada e preparada para atender diferentes demandas que podem ser mais ou menos desafiadores a depender da extensão da experiência profissional que cada um tennha.

Em outras palavras, um olhar jovem sem experiência adversarial pode tornar a atuação colaborativa de toda a equipe mais confortável, a medida que ele não foi contaminado pelos hábitos adversariais que a maioria de seus colegas herdeu de sua ampla experiência belicosa. Por outro lado, o profissional veterano naturalmente agrega conhecimento e táticas que só a experiência é capaz de proporcional. É exatamente por isso que uma equipe em que ambos possam participar conta com abordagens diferentes e complementares que ajudam a gestão sistêmica ideal do conflito.

Já que não se tem acesso à este tipo de formação nas universidades, pelo menos não de maneira institucionalizada, o Instituto Brasileiro de Práticas Colaborativas vem promovendo cursos para capacitar profissionais e certifica-los enquanto colaborativos. Essas capacitações acontecem em 
vários Estados do Brasil ${ }^{103}$ e tem o objetivo de dissiminar as práticas e disponibilizar ferramentas para atuação profisisonal nesse sentido.

Esses cursos são direcionados a profissionais de todas as áreas mencionadas neste trabalho, inclusive, é claro, aos estudantes ainda na graduação. A certificação fornecida pelo IBPC, entretanto, não é um pré requisito para atuar em um caso colaborativo. Apesar de ser útil o estudo intensivo do tema proporcionado pela capacitação, basta a postura colaborativa e a assinatura do Pacto de Não Litigância pelos profissionais para promover um divórcio colaborativo.

A medida que este método for pulverizado, com sorte não será mais necessário providenciar esta formação paralela, a medida que se espera a urgente inserção de métodos autocompositivos, como este, na grade curricular das faculdades. Entretanto, até que isto aconteca, o que se observa é a dissiminação do tema através de grupos de Estudo.

Inconformado com a manutenção do mesmo programa de curso, considerando a nítida e gritante mudança do corpo dicente e dos clientes, são os próprios alunos que vem promovendo estes encontros com o objetivo de incentivar o dinamismo educacional e possibilitar que jovens advogados se formem com o conhecimento mínimo acerca do que são as Práticas Colaborativas.

Mesmo que, depois de conhecê-las, optem por uma carreira adversarial.

À vista disto, somente se os alunos tivessem acesso à essa informação é que eles poderão se tornar advogados conscientes que aconselham seus clientes a dar o encaminhamento adequado de suas demandas ${ }^{104}$. Em outras palavras, a apresentação do Sistema Multiportas que se espera do novo advogado só poderá se concretizar se esse profissional efetivamente conhecer

Página do Instituto Brasileiro de Práticas Colaborativas, na qual é possível encontrar os Estados nos quais já existem profissionais colaborativos. IBPC. Disponível em:

<https://www.praticascolaborativas.com.br/localize-um-profissional>. Acesso em: 5 jun. 2019.

${ }^{104}$ MACFARLANE, 2008, p. 143. 
todas as portas que o compõe. É só por meio da exposição de todas essas possibilidades ao cliente, que será efetivamente será garantido o acesso à justiça $^{105}$.

Nesse sentido, conclui-se que atuar colaborativamente não significa diminuição da importância do advogado, e sim aumento de sua responsabilidade enquanto tal. Isto, porque ele é o engarregado da importantíssima tarefa de apresentar ao cliente leigo a vasta gama de oportunidades diferentes de gestão de seu conflito ${ }^{106}$, influenciando diretamente na qualidade desta experiência. 


\section{CONSIDERAÇÕES FINAIS}

Considerando todas as reflexões aqui expostas, entendemos que as Práticas Colaborativas não só estão de acordo com a atual lógica autocompositva do Direito Brasileiro, como também são fundamentais quando tratamos de conflitos familiares. Este método representa o resgate da autonomia da vontade, o olhar e escuta cuidadosos em relação aos filhos do divórcio e a retomada dos valores éticos mais fundamentais da carreira jurídica.

Com pouco menos de 10 anos da EC 66, que eliminou a discussão de culpa no divórcio, é nítido que ainda existe uma resistência cultural em relação a desjudicialização desse tema. Mesmo assim, como analisado por meio do presente trabalho, o convite do divórcio colaborativo oferece inúmeros benefícios objetivos que estão de acordo a sociedade plural e protagonista que desejamos.

Apesar de muito vantajosa, a aplicação das Práticas ao Divórcio no Brasil apresenta um desafio que não pode ser ignorado. $\mathrm{O}$ mito da equipe completa, entendido como a filosofia de que só é Prática Colaborativa se formada uma equipe multidisciplinar com todos os possíveis integrantes, é preocupante. Em que pese benéfice a formação da equipe, sua imposição como requisito para o divórcio colaborativo pode tornar o processo oneroso demais.

Para muitos a ideia de contar com um time de profisisonais para lidar com o divórcio, além de assustadora, pode representar um investimento financeiro incompatível possibilidades da família. Por isso, é preciso ter em mente que a única regra da ideia revolucionária de Stuart Webb é a assinatura do Pacto de Não litigância pelos advogados envolvidos no divórcio.

O que for determinado para além disso, como a constituição ou não de equipe, é espaço de total autonomia de vontade das partes e customização do processo com base das demandas específicas daquela família. Da mesma 
forma que já colocou Ronald Ousky, não se trata de um procedimento "tamanho único", pelo contrário. Por ser a Alfaiataria do Direito, os divorciandos podem e devem ter liberdade para desenharem suas equipes de acordo com suas expectativas jurídicas, emocionais e financeiras.

Por parte dos advogados, como já foi colocado, também existe uma resistência a atuação cordial e não adversarial característica das Práticas Colaborativas. Pode ser difícil a adaptação para uma nova maneira de trabalhar, por isso só com o tempo será possível mudar a realidade dessa profissão. Isso também só será viabilizado se estivermos constantemente reavaliando como podemos melhor atender nossos clientes. Trata-se de um desafio a ser enfrentado com coragem, humildade e, principalmente, muita curiosidade. É preciso ter a consciência de que um bom profissional é aquele que está sempre aprendendo e, portanto, questionando constantemente suas próprias certezas.

Essa mudança, por sua vez, precisa ter início no ambiente estudantil. A dissiminação das Práticas nas universidades, portanto, representa mais um desafio que depende de alguma flexibilização desses departamentos de direito das universidades, que não mais podem oferecer a mesma grade acadêmica que utilizaram outrora. Hoje o que se apresenta é um corpo dicente com expectativas completamente diferentes, por todos os motivos aqui expostos, sendo imperativo que a grade acadêmica o acompanhe.

É certo, portanto, que o caminho a ser percorrido é longo e de muito trabalho até que o divórcio colaborativo seja efetivamente uma realidade no Brasil. É certo também, por outro lado, que o destino daqueles que o estão trilhando é o de uma advocacia caracterizada pela coragem, respeito e boa fé. Entendemos ser esse um objetivo nobre o suficiente para demandar engajamento e dedicação rumo à uma profissão mais ética, humana e honesta.

Deixamos, finalmente, uma última reflexão acerca do termo mudança quando pensamos os dois paradigmas expostos no presente trabalho. A beligerância é tão latente no mundo jurídico, que a proposta de conduta 
conciliatória e colaborativa parece revolucionária. Seu atingimento soa como um sacrifício hercúleo por parte do advogdo, que se transforma em um herói quando alcança a tão sonhada mudança do paradigma.

Entretanto, uma atuação colaborativa nada mais é do que os ditames éticos preconizados pela profissão ha anos, postos em prática. É certo que a função do advogado possui um caráter libertário - como restou amplamente demonstrado através do Código de Ética que temos hoje - e que, em algum momento no percurso isso se perdeu, acarretando o cenário extremadamente litigante com o qual nos deparamos hoje. Assumir o paradigma colaborativo significa, portanto, um resgate da gêneses desta profissão em um momento em se mais tem urgência no incentivo ao diálogo, afeto e respeito.

Parece ser o este o único meio possível de realmente transformar a sociedade em que vivemos. Afinal, a julgar pelos resultados da ampla postura combativa que tivemos até agora, que outra alternativa nos resta? 


\section{REFERÊNCIAS BIBLIOGRÁFICAS}

BRASIL. Ato Institucional 5/68. Disponível em:

<http://www.planalto.gov.br/ccivil_03/AIT/ait-05-68.htm>. Acesso em: 20 mai. 2019.

BRASIL. Ato Institucional 5/75. Disponível em:

$<$ https://presrepublica.jusbrasil.com.br/legislacao/103910/emenda-

constitucional-5-75.htm >. Acesso em: 16 jun. 2019.

BRASIL. Código Civil de 1916. Disponível em:

<http://www.planalto.gov.br/ccivil_03/leis/13071.htm>. Acesso em: 20 mai. 2019.

BRASIL. Código de Processo Civil de 2015. Disponível em:

<http://www.planalto.gov.br/ccivil_03/_ato2015-

2018/2015/lei/113105.htm>. Acesso em: 20 mai. 19.

BRASIL. Constituição Brasileira de 1891. Disponível em:

<http://www.planalto.gov.br/ccivil_03/constituicao/constituicao91.htm>.

Acesso em: 20 mai. 2019.

BRASIL. Constituição de 1824. Disponível em:

<http://www.planalto.gov.br/ccivil_03/Constituicao/Constituicao24.htm>.

Acesso em: 20 mai. 2019.

BRASIL. Constituição de 1934. Disponível em:

<http://www.planalto.gov.br/ccivil_03/constituicao/constituicao34.htm>.

Acesso em: 20 mai. 2019.

BRASIL. Constituição de 1937. Disponível em:

<http://www.planalto.gov.br/ccivil_03/constituicao/constituicao37.htm>. Acesso em: 20 mai. 2019.

BRASIL. Constituição de 1947. Disponível em:

<http://www.planalto.gov.br/ccivil_03/constituicao/constituicao46.htm>.

Acesso em: 20 mai. 2019.

BRASIL. Constituição de 1967. Disponível em:

<http://www.planalto.gov.br/ccivil_03/constituicao/constituicao67emc69.ht m>. Acesso em: 20 mai. 2019. 
BRASIL. Constituição de 1988. Disponível em:

<http://www.planalto.gov.br/ccivil_03/constituicao/constituicaocompilado. htm>. Acesso em: 20 mai. 2019.

BRASIL. Decreto de 3/11/1827. Disponível em: <http://www.planalto.gov.br/ccivil_03/leis/lim/LIM-3-11-1827.htm>. Acesso em: 20 mai. 2019.

BRASIL. Decreto $n^{\circ} 1.144$ de 1861. Disponível em: <https://www2.camara.leg.br/legin/fed/decret/1824-1899/decreto-1144-11setembro-1861-555517-publicacaooriginal-74767-pl.html>. Acesso em: 20 mai. 2019.

BRASIL. Decreto $n^{\circ} 181$ de 1890. Disponível em: <http://www.planalto.gov.br/ccivil_03/decreto/1851-1899/D181.htm>. Acesso em: 20 mai. 2019.

BRASIL. Emenda Constitucional 1 de 1969. Disponível em: <http://www.planalto.gov.br/ccivil_03/constituicao/emendas/emc_anterior1 988/emc01-69.htm>. Acesso em: 20 mai. 2019.

BRASIL. Emenda Constitucional 66/10. Disponível em: <http://www.planalto.gov.br/ccivil_03/constituicao/emendas/emc/emc66.ht m>. Acesso em: 20 mai. 2019.

BRASIL. Emenda Constitucional 8/77. Disponível em: <http://www.planalto.gov.br/ccivil_03/Constituicao/Emendas/Emc_anterior 1988/emc08-77.htm>. Acesso em: 20 mai. 2019.

BRASIL. Emenda Constitucional 9/77. Disponível em: <https://presrepublica.jusbrasil.com.br/legislacao/103919/emendaconstitucional-9-77>. Acesso em: 20 mai. 2019.

BRASIL. Lei $n^{\circ}$ 6.515/77. Disponível em: <http://www.planalto.gov.br/ccivil_03/leis/16515.htm>. Acesso em: 20 mai. 2019.

BRASIL. Resp 1247098/MS. Recurso Especial 2011/0074787-0/. Relatora Ministra Maria Isabel Gallotti. $4^{\text {a }}$ Turma. Julgamento em: 14/03/2017.

BRASIL. STJ. Disponível em: <http://www.stj.jus.br/sites/STJ/default/pt_BR/Comunicação/noticias/Not\% C3\%ADcias/Divórcio-e-separação-coexistem-no-ordenamentojur\%C3\%ADdico-mesmo-após-EC-66>. Acesso em: 11 jun. 2019. 
CARTA de Stuart Webb ao Juiz "Sandy" Keith. Disponível em: $<$ https://abcfamilyblog.wordpress.com/2015/07/04/the-origins-ofcollaborative-divorce-stu-webbs-letter/>. Acesso em: 20 mai. 2019.

CARVALHO NETO, Inacio de. Separação e Divórico Teoria e Prática. 2007.

CNJ. Relatório Justiça em Números. Disponível em: <http://www.cnj.jus.br/files/conteudo/arquivo/2018/09/da64a36ddee693ddf 735b9ec03319e84.pdf>. Acesso em: 20 mai. 2019.

CNJ. Resolução 125 de 2010. Disponível em <http://www.cnj.jus.br/buscaatos-adm?documento=2579>. Acesso em: 21 mai. 2019.

DIAS, Maria Berenice. Manual de Direito das Famílias. $7^{\mathrm{a}}$ ed. São Paulo: Ed. Revista dos Tribunais, 2010.

. Separação e Divórcio. Disponível em:

<http://www.mariaberenice.com.br/manager/arq/(cod2_764)10_da_separa cao_e_do_divorcio.pdf $>$. Acesso em: 21 mai. 2019.

FIORI, Vera. Divórcio à brasileira. Disponível em: <https://emais.estadao.com.br/noticias/geral,divorcio-a-brasileira,22666>. Acesso em: 11 jun. 2019.

FISHER, Roger et al. Como Chegar ao Sim. Ed. Sextante, 2018. p. 63.

FORREST S., Monsten. Collaborative Divorce Handbook. Jossey-Bass, CA, USA, 2009.

I JORNADA de Prevenção e Solução Extrajudicial de Litígios. Disponível em: <https://www.cjf.jus.br/cjf/corregedoria-da-justica-federal/centro-deestudos-judiciarios-1/publicacoes-1/cjf/corregedoria-da-justicafederal/centro-de-estudos-judiciarios-1/prevencao-e-solucao-extrajudicialde-

litigios/?_authenticator=60c7f30ef0d8002d17dbe298563b6fa2849c6669>. Acesso em: 20 mai. 2019.

IACP. Disponível em: 〈https://www.collaborativepractice.com>. Acesso em: 23 mai. 2019.

Padrões de Conduta e Ética do IACP. Disponível em:

<https://docs.wixstatic.com/ugd/9da3b3_9a21e293dcc3486f8ded50665e6b4 f3f.pdf $>$. Acesso em: 29 mai. 2019. 
IBPC. Disponível em: <https://www.praticascolaborativas.com.br/localizeum-profissional>. Acesso em: 5 jun. 2019.

MACFARLANE, Julie. The New Lawyer: How Settlement is Transforming the Practice of Law. Canadá: Ed. UBC Press, 2008.

MOSTEN, S. Forrest; CORDOVER B., Adam. Bulding a Successful Collaborative Family Law Practice. Ed. ABA Section of Family Law, 2017.

OAB. Código de Ética e Disciplina da Ordem dos Advogados do Brasil. Disponível em: <https://www.oab.org.br/visualizador/19/codigo-de-etica-edisciplina>. Acesso em: 20 mai. 2019.

OUSKY, Ronald; WEBB, Stuart. O Caminho Colaborativo para o Divórcio. Publicado Instituto Brasileiro de Práticas Colaborativas. Rio de Janeiro, 2017.

PEREIRA, Rodrigo da Cunha. Divórcio é decorrência natural do casamento por amor. Disponível em: <https://www.conjur.com.br/2012-jul-24/rodrigopereira-divorcio-decorrencia-natural-casamento-amor>. Acesso em: 21 mai. 2019.

Divórcio Teoria e Prática. 2ª ed. Rio de Janeiro: G Z Editora, 2010.

PREMIO INOVARE. Disponível em:

$<$ https://www.premioinnovare.com.br/praticas/1/praticas-colaborativas-nodireito-de-familia>. Acesso em: 20 mai. 2019.

PUC-Rio. Disponível em: <https://www.puc-

rio.br/ensinopesq/ccg/direito.html>. Acesso em: 11 jun. 2019.

SINSA. Disponível em: <https://www.conjur.com.br/2016-ago12/advocacia-devera-evitar-demandas-nao-propo-lasbarroso?fbclid=IwAR3EHUVjXTxvgwXyj9zzi9Z6C7NAUCddgxCDhFxw-7zObrxdtbvfKxGguw>. Acesso em: 30 mai. 2019.

TELLES, Marília Campos Olveira e. Um Olhar Multidisciplinar sobre o Cuidado na Resolução de Conflitos: Mediação e Práticas Colaborativas. Disponível em: <https://www.linkedin.com/pulse/um-olharmultidisciplinar-sobre-cuidado-na-resolução-mar\%C3\%ADlia-campos/> . Acesso em: 22 mai. 2019. 
THE Causes of Popular Dissatisfaction with the Administration of Justice. Pound Conference de 1976. Disponível em:

$<$ https://law.uoregon.edu/images/uploads/entries/Michael_Moffitt-

Before_the_Big_Bang-The_Making_of_an_ADR_Pioneer.pdf $>$. Acesso em: 20 mai. 2019.

THE resolution of conflict: constructive and destructive processes. New Haven and London: Yale University Press, 1973. p. 1-32; 349-400.

VAINER, Ricardo. Anatomia de um Divórcio Interminável: o litígio como forma de vínculo, uma abordagem interdisciplinar. Ed. Casa do Psicologo, 1999. 